\title{
Geomorphology of the Gubbio Basin (Central Italy): understanding the active tectonics and earthquake potential
}

\author{
Stefano Pucci, Paolo Marco De Martini, Daniela Pantosti and Gianluca Valensise \\ Istituto Nazionale di Geofisica e Vulcanologia, Sezione di Roma 1 - Sismologia e Tettonofisica, Roma, Italy
}

\begin{abstract}
The Gubbio Basin is a $22 \mathrm{~km}$ long, $4 \mathrm{~km}$ wide depression located within the North-Central Apennines fold-andthrust belt. The basin is bounded to the east by the Gubbio Fault, a W-dipping, normal fault dissecting a large Jurassic-Oligocene anticline. Although located along one of the main seismogenic zones of the Peninsula, both historical and instrumental is seismicity is limited with the only exception for the 29 April 1984, $M_{s} 5.3$ earthquake, which occurred about $10 \mathrm{~km}$ southwest of the basin. Most of the literature attributes this seismicity to the Gubbio Fault. New geomorphic and geologic investigations based on field and aerial photo surveys and DEM analyses provide new insights on the active faulting in the area and are used to infer potential seismogenic sources. Limited evidence of ongoing deformation along the surface expression of the Gubbio Fault was found, possibly because of low rates of deformation versus fast erosional processes. The western side of the basin appears to be controlled by an east-dipping normal fault, antithetic to the Gubbio Fault. Standard dislocation modeling was used to understand the role played by the Gubbio Fault and its antithetic. The Gubbio Fault was divided into a high-angle section above $3.5 \mathrm{~km}$ and a low-angle section between 3.5 and $6 \mathrm{~km}$ depth. Based on different tests we conclude that both sections of the Gubbio Fault as well as the antitethic fault contributed to the present setting of the basin. At present the antithetic fault appears to be the most effective in producing a geomorphic signature and controlling the basin width. The high-angle Gubbio Fault played a major role in the basin growth but now its activity rate appears minor. Because of the characteristics and location of the 1984 earthquake, the low-angle Gubbio Fault is assumed to be presently active and seismogenic. Based on the integration of geologic, geomorphic and seismological data we suggest that the low-angle Gubbio Fault is formed by two individual sources capable of $M$ 5.3-5.9 earthquakes. The southern source ruptured in the 1984 earthquake while the northern source did not rupture recently nor historically.
\end{abstract}

Key words tectonic geomorphology - normal fault seismogenic sources - Umbria-Marche Apennines 29 April 1984 Gubbio earthquake

\section{Introduction}

The Gubbio Basin is one of the most prominent intramountain basins in the Central Apen-

Mailing address: Dr. Stefano Pucci, Istituto Nazionale di Geofisica e Vulcanologia, Sezione di Roma 1 Sismologia e Tettonofisica, Via di Vigna Murata 605, 00143 Roma, Italy; e-mail: pucci@ingv.it nines. It is bounded to the east by an impressive normal fault known as Gubbio Fault that is part of the seismogenic Umbrian fault system (Barchi, 2002). Even though the basin overlies inferred seismogenic sources including that responsible for the 1984 M 5.3 earthquake (Valensise and Pantosti, 2001a,b), seismicity (both historical and instrumental; CPTI, Working Group, 1999; INGV, 1985-2000) is relatively infrequent and not sufficient for a full understanding of the seismogenic potential of the area.

To assess the seismic potential of the Gubbio Basin with confidence we must first answer these questions: 


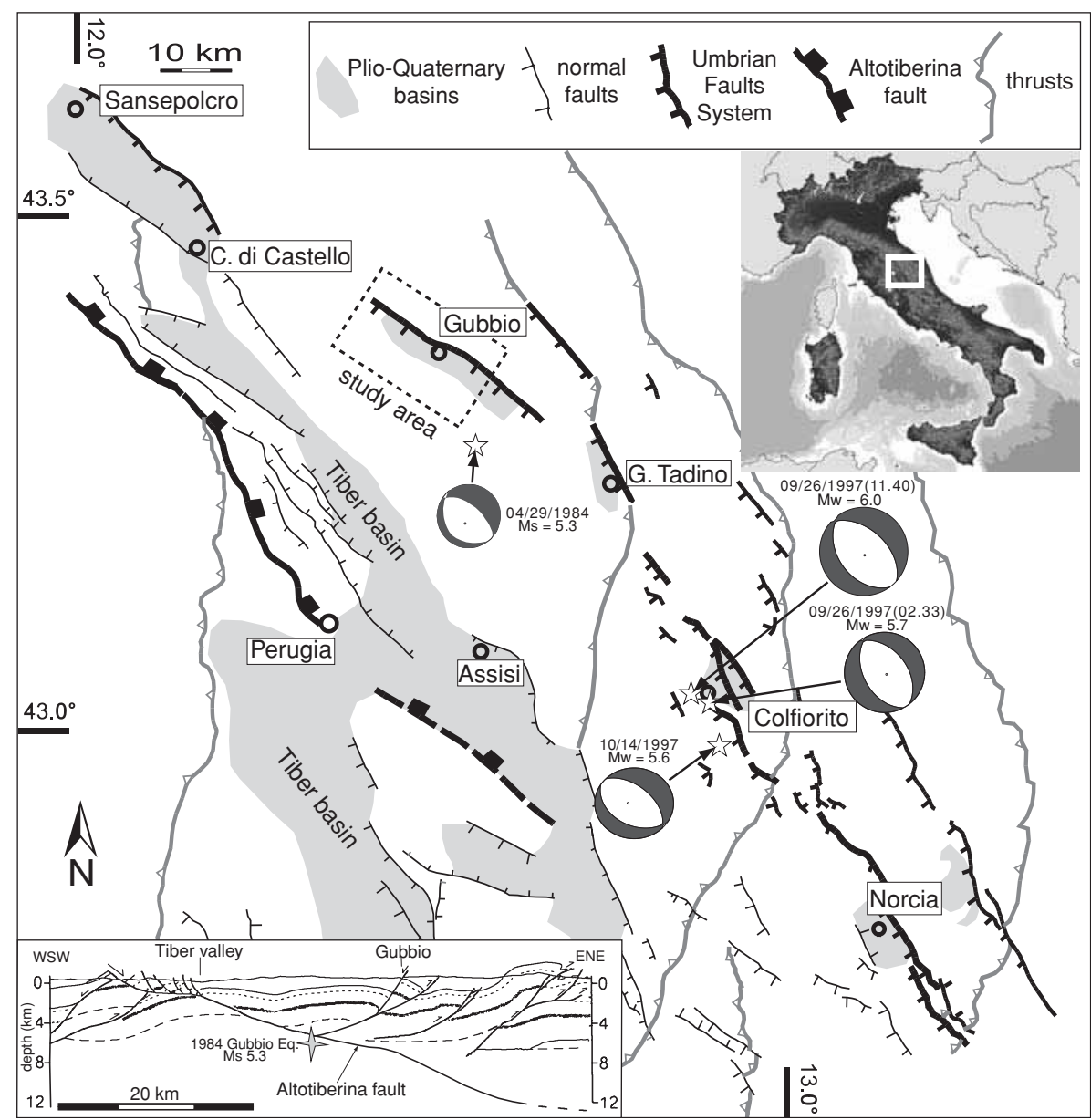

Fig. 1. Structural sketch of the Umbria-Marche domain (from Barchi et al., 2001, modified) showing the alignment of the intramountain basins along the Umbrian Fault System (sensu Barchi, 2002), which coincides with the main seismogenic zone of Central Apennines defined by Valensise and Pantosti (2001a). Focal mechanisms and magnitudes are for the 1997, Colfiorito sequence from Ekström et al. (1998) and for the 1984 Gubbio earthquake from Dziewonski et al. (1985) and ISC (2001). The lower left inset includes a schematic regional geological section integrated with the interpretation of seismic profiles and showing also the 1984 Gubbio earthquake mainshock location (after Boncio et al., 1998, modified).

How many seismogenic sources lie beneath the basin?

What is its (their) geometry?

What is the largest earthquake expected for the area?

What is the expected seismic behavior of this (these) source(s)?
Notwithstanding a rich literature describing various aspects of the basin geology and structure, limited attention was devoted to active tectonics and particularly to the study of landscape as a direct response of repeated coseismic surface deformation (Selvaggi and Sylos Labini, 1989; Menichetti, 1992; Boncio et al., 1996). 
To contribute to the understanding of the local earthquake potential we investigated the relationships between seismicity and tectonics by carrying out new geomorphic studies of the Gubbio Basin based on field and aerial photo surveys and DEM analyses. Our approach is based on the awareness that landscape evolution may contribute to describing the seismic history of a region. We also compared the deformation patterns of different combinations of active faults based on standard dislocation modeling. In the following we summarize the present knowledge on the area, present the new geomorphic data, and discuss different alternatives of seismogenic source geometry and their possible implications for defining the activity of the Gubbio Basin.

\section{The Gubbio Basin}

\subsection{Geological and structural setting}

The study area is located in the inner part of the Umbria-Marche Apennines (Central Italy) (Lavecchia and Pialli, 1980). A thick skinned style of compressional deformation, characterized by a system of multiple superposed detachments, generated a set of NW-SE trending, NEverging folds and thrusts during LanghianSerravallian (Barchi, 1991; Barchi et al., 1998). The result of the eastward migration of the deep detachment layers (base of the carbonatic multilayer) is the deformation of the more external, partially grown structure such as the upper detachment layers located within Miocene flysch formations. The bedrock of the area is composed by the upper part of the Umbria-Marche sequence: a pelagic carbonatic multilayer (Jurassic-Oligocene) overlain by a Miocene flysch sequence (Bonarelli et al., 1952; Moretti and Perno, 1968; Damiani et al., 1983; Menichetti and Pialli, 1986). The Gubbio Basin is bounded to the east by one major box-shaped, NE-verging carbonatic anticline (referred to as Gubbio anticline), whereas to the west it is bounded by folded flysch deposits (Bonarelli et al., 1952; Moretti and Perno, 1968) (fig. 2).

Starting in Lower Pleistocene, extension took over the compressional tectonics producing structures with a main NW-SE direction.
West of the Gubbio Basin, high-angle normal faults both SW and NE dipping are recognized (Menichetti and Minelli, 1991; Menichetti, 1992). However, the most impressive extensional structure bounds the basin to the east and is likely the NW-striking, SW-dipping, Gubbio Fault which dissects, parallel to its axis, the Gubbio anticline down-throwing the SW flank well below the basin sediments. It consists of a $120^{\circ}$ - to $150^{\circ}$-striking, $50^{\circ}$ - to $70^{\circ}$-dipping fault planes, which, as a whole, show a gentle bend (Collettini, 2001) (fig. 2).

The clear result of the long-term activity of the Gubbio Fault is the topographic low, coinciding with the Gubbio Basin, filled by continental deposits (GE.MI.NA, 1963) (fig. 2). They consist of a sequence of three main sedimentary units, resulting from the evolution of the deposition from lacustrine toward fluvial environment: 1) clayey-lignitic basal complex, characterized by meter-thick lignite layers interbedded with organic gray clay, locally with sand and conglomerates; 2) clayey-sandy complex comprising sand, sandy clay interbedded with sandstone conglomerate lenses; 3) upper alluvial complex, composed by organic sandyclayey matrix with calcareous conglomerate. On the basis of palinological analysis, the unit 1 is referred to the interglacial period GünzMindel (500-400 Ky) (GE.MI.NA, 1963) or to the Lower Pleistocene (Lona and Bertoldi, 1972), this latter estimate is in agreement with the fossil fauna (lacustrine facies) found in this layer (Bonarelli, 1891).

Data to attempt a reconstruction of the subsurface setting of the basin are available too. Deep boreholes by GE.MI.NA (1963) were used to infer the geometry of the basin and of the filling deposits. By correlating their stratigraphy GE.MI.NA (1963) imaged: 1) NE-dipping deposits, with dips generally increasing toward the Gubbio Fault; 2) a deepening toward NE of the bedrock/basin filling deposit contact; 3) a Pleistocene depocentre, up to $500 \mathrm{~m}$ below the present basin surface, located close to the Gubbio Fault. However, because of the uneven distribution of the boreholes in the basin (mainly located along the western side and in the southern part) this reconstruction contains large uncertainty. Menichetti (1992) re-interpreted 
these data integrating them with more recent boreholes stratigraphy and new electrical and seismic surveying parallel and perpendicular to the basin (Giaquinto et al., 1991), reconstructing the geometry of the pre-Pleistocene bedrock. He describes the basin as the typical result of the evolution of an half-graben, with a wedge geometry, and progressive thickening of the lacustrine deposits controlled by a SW-dipping normal fault: the Gubbio Fault. However, this reconstruction shows a peculiar bathtub shape, about $400 \mathrm{~m}$ deep, with flat bottom and long steep facing flanks. The pre-Pleistocene depocentre, deeper in the northern part of the basin, appears to be centered within the valley, with a geometry that is not expected for a typical half-graben (fig. 3a).
Recently, commercial reflection profiles allowed Barchi et al. (2000) to perform a detailed reconstruction of the Gubbio fault isobaths. The resulting picture of the fault plane at depth shows an high-angle dip of the upper fault portion and a low-angle dip below $\sim 3.5 \mathrm{~km}$, due to the reactivation of a pre-existing thrust plane. The interpretation of these seismic profiles images the Gubbio Fault as an antithetic of the E-dipping, low-angle, Altotiberina Fault (fig. 1; Barchi et al., 1998; Boncio et al., 1998). The Altotiberina Fault is a major extensional discontinuity in the Umbria-Marche Apennines. It affects the upper crust, at least up to $15 \mathrm{~km}$ depth, beneath the thrust and fold belt. The Altotiberina Fault follows a staircase trajectory

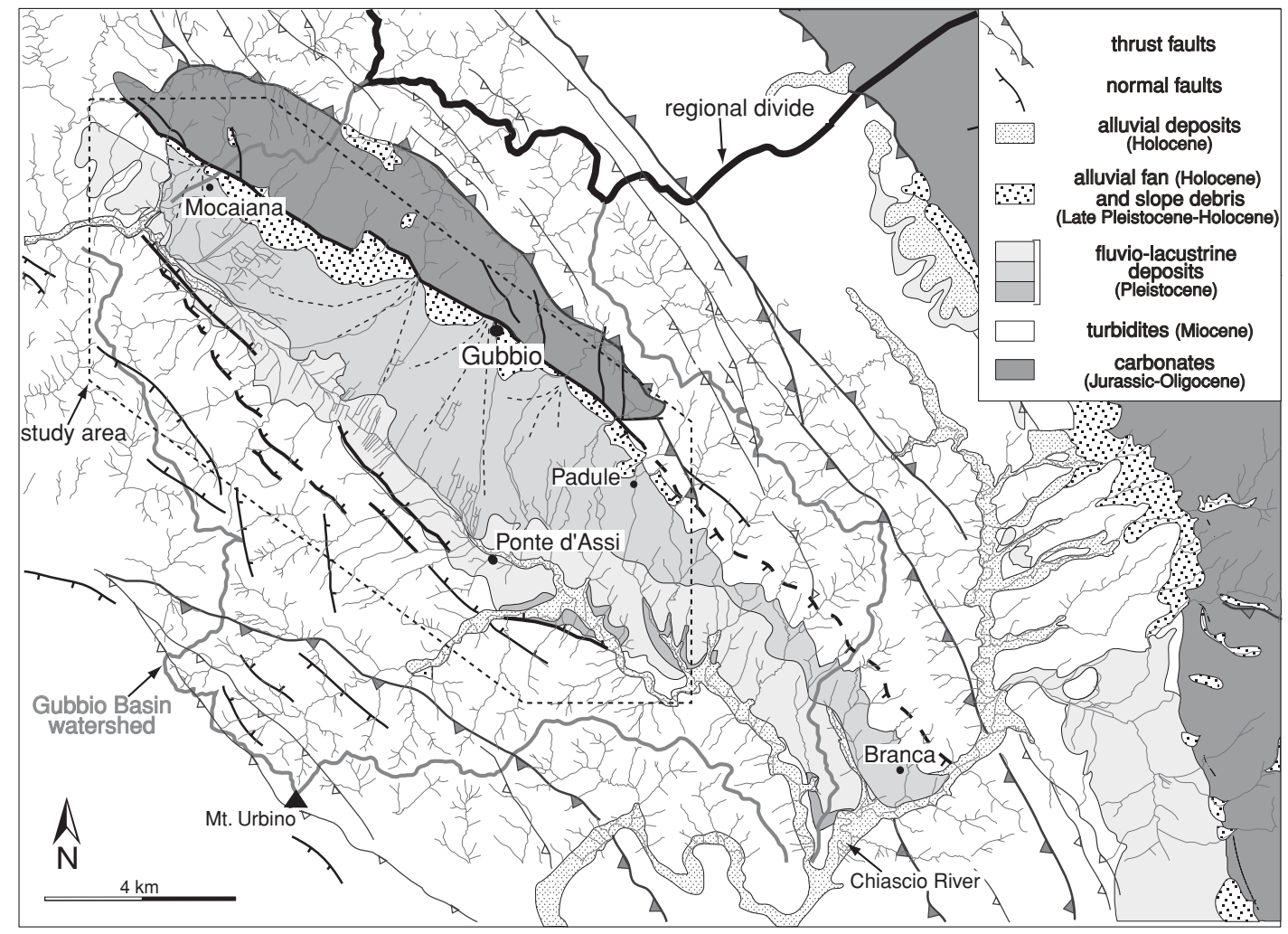

Fig. 2. Simplified geological map of the Gubbio Basin. Thick normal faults are discussed in this work (after Bonarelli et al., 1952; Moretti and Perno, 1968; Menichetti and Pialli, 1986; Collettini, 2001, modified). 

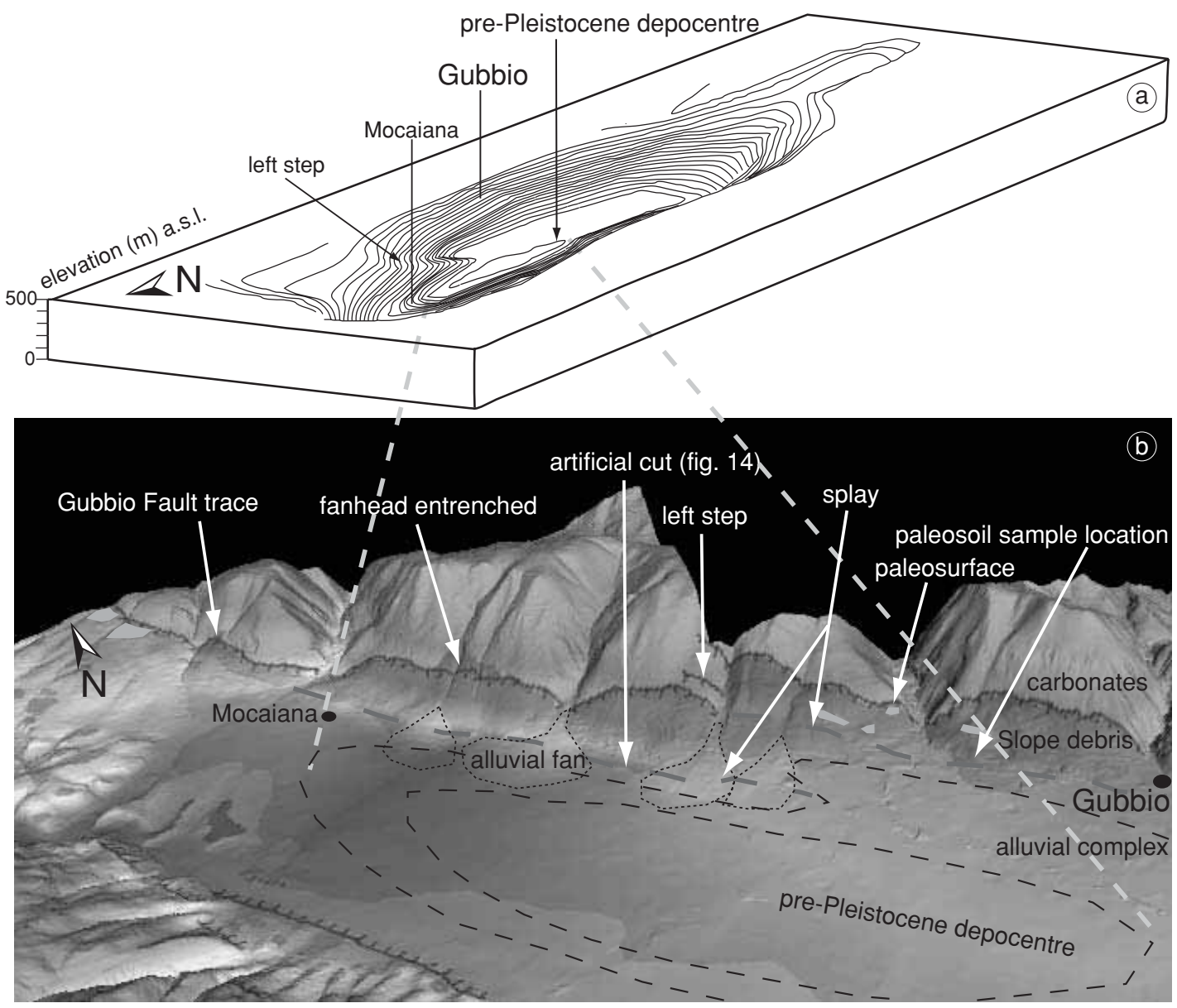

Fig. 3a,b. a) 3D reconstruction of the pre-Pleistocene basement (after Menichetti, 1992, redrawn); b) 3D view of the northeastern side of the Gubbio Basin derived by 5-m resolution DEM. Hypothesized Gubbio Fault splays are reported along with to the location of the northern part of the pre-Pleistocene depocentre suggested by Menichetti (1992).

and shows an offset as much as $5 \mathrm{~km}$. The isobaths of the Gubbio Fault confirm that the left bending of the structure, shown by its surface trace, is well recognizable even at depth (Barchi et al., 2000). The isobaths of the Gubbio Fault also display a rise of the branch line with the Altotiberina Fault from $6 \mathrm{~km}$ in the southern part to $4.5 \mathrm{~km}$ in the central part to get deeper again toward the north. The analysis of denser seismic profiles array allowed Mirabella (2003) to derive additional characteristics of the Gubbio Fault. The fault boundaries are quite consistent with the end of the basin to the north, whereas, to the south the fault appears to continue even outside the basin for a total length of about $30 \mathrm{~km}$ although with minor evidence (fig. 4). The total throw of the Gubbio Fault along strike reaches a maximum of about $2500 \mathrm{~m}$ near the town of Gubbio and shows a sharp decrease toward the northern and southern tips (Mirabella, 2003). 


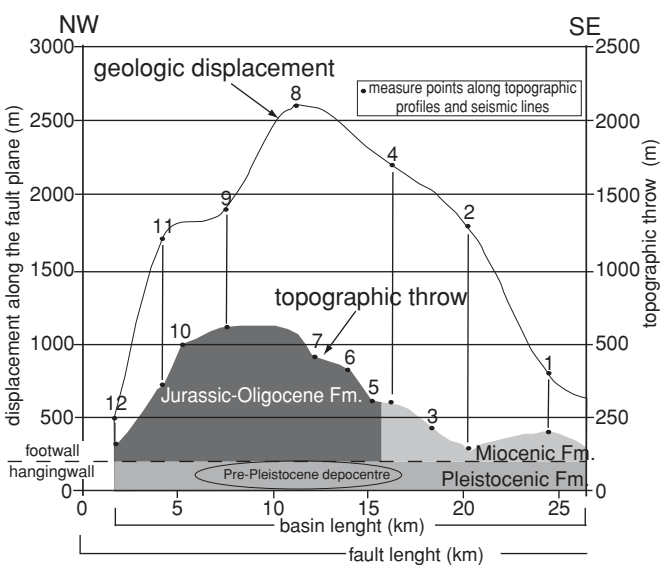

Fig. 4. Comparison between geologic displacement and topographic throw along the Gubbio Fault strike. Geologic throw has been calculated by using seismic lines on the base of the Marne a Fucoidi beds (115-95 My) offset (from Mirabella, 2003). Topographic throw is measured as difference between highest elevation and surface of the basin. The position of the prePleistocene depocentre, as reconstructed by Menichetti (1992), the basin length and the lithologies cropping out in the fault footwall are reported too.

\subsection{Seismicity}

The Gubbio Basin is located within the main NW-SE Apennines seismogenic belt, which extends from Tuscany to Calabria (Valensise and Pantosti, 2001a). In the Umbria-Marche region, most of the historical and instrumental seismicity is related to the activity of the NNW-SSE trending SW dipping normal faults alignment (Umbria fault system, sensu Barchi et al., 2000). This system extends through the intra-mountain basins of Norcia, Colfiorito, Gualdo Tadino, Gubbio and Sansepolcro (fig. 1).

Historical earthquakes of $I>$ VII MCS (Mercalli-Cancani-Sieberg scale) are located both to the north (Citerna-Monterchi, April $1917 I_{\max }=$ = IX; Cagli, June $1781 I_{\max }=$ IX-X; Monterchi, December $1352 I_{\max }=$ IX; Città di Castello, April $1458 I_{\max }=\mathrm{IX}$; Valtiberina, September $1789 I_{\max }=$ VIII-IX; Bocca Serriola, October $1389 I_{\max }=$ IX; CPTI, Working Group, 1999) and to the south (Gubbio, April $1593 I_{\max }=$ VII; Gualdo Tadino,
July $1751 I_{\max }=X$; Fiuminata, April $1747 I_{\max }=$ = IX; Camerino, April $1279 I_{\max }=\mathrm{X}$; CPTI, Working Group, 1999) of the Gubbio Basin.

Instrumental seismicity $\left(M_{d}>1.5\right)$, recorded in the region by the Istituto Nazionale di Geofisica e Vulcanologia in the period 1985-2000 (INGV, 1985-2000), is mainly located south of the Gubbio Basin and it is related to the 19971998 Colfiorito earthquake sequence characterized by normal faulting events (fig. 5).

On April 29, 1984 the study area was struck by a $M_{s} 5.3$ (NEIC) earthquake $\left(M_{O}\right.$ $3.410^{24}$ dyne $\cdot \mathrm{cm}$; Dziewonski et al., 1985) located at Mt. Urbino, about $10 \mathrm{~km}$ south of the town of Gubbio at $7 \mathrm{~km}$ depth (ISC, 2001). A local network, set in the epicentral area two days after the mainshock, recorded 300 aftershocks, 4 of which had $M_{s}>4.0$. The aftershocks occurred in an area of about $20 \times 6 \mathrm{~km}$ elongated in a $\mathrm{N} 140^{\circ}$ direction. Their distribution appears to delineate two linear parallel clusters, the southernmost of which is denser and includes also the mainshock (see inset in fig. 4). These clusters describe two high-angle, west-dipping planes, the northernmost being characterized by superficial events with hypocentral determinations between 3 and $5 \mathrm{~km}$ (Haessler et al., 1988). These planes are located 7-12 km west of the Gubbio Fault and seem to be not directly related to this major structure (Collettini et al., 2003). The CMT (Dziewonski et al., 1985) and first-motion (Westaway et al., 1989) focal mechanism solutions of the mainshock agree substantially on fault strike and kinematics but not on fault dip (see inset in fig. 5). The 1984 Gubbio earthquake instrumental data has been used in the definition of three seismogenic sources recently published in Valensise and Pantosti (2001b). They solved the discrepancy between aftershock distribution and CMT focal mechanism, which better fits the Gubbio fault at depth, as possibly due to the fact that aftershocks were recorded a few days after the mainshock and thus may not directly be related to the main fault but to stress readjustment within the fault hangingwall.

In May and June 1987 a local network was installed again in the area (Deschamps et al., 1989) and four hundreds events with magnitude between 0.8 and 3.1 were recorded. These were 


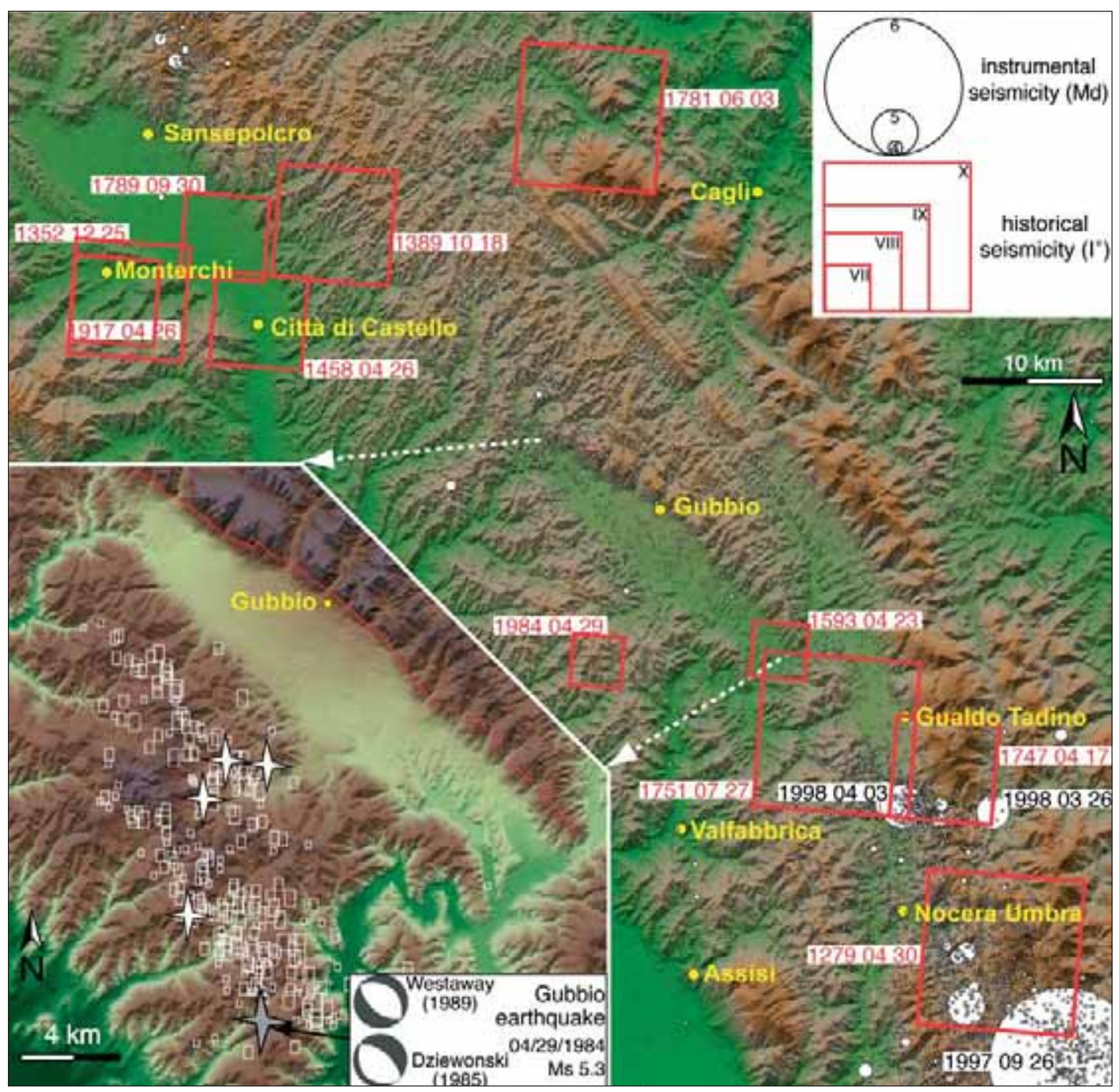

Fig. 5. Instrumental and historical seismicity of the Gubbio Basin area. Historical seismicity with intensity larger than VII MCS is reported for the period 217 B.C.-1991 A.C. (CPTI, Working Group, 1999). The inset shows the 4/29/1984 Gubbio earthquake sequence; gray star shows the mainshock, white stars show aftershocks with $M>4$ and rectangles show aftershocks with $M<4$ (modified after Haessler et al., 1988). Focal mechanism parameters: strike 143 dip 21 rake - 72, strike 304 dip 70 rake - 97 (Dziewonski et al., 1985); strike 135 dip 55 rake - 90, strike 315 dip 35 rake - 90 (Westaway et al., 1989).

organized in two clusters NW-SE trending located near Gubbio and Valfabbrica towns. 58\% of the hypocentral determinations concentrated between 3 and $7 \mathrm{~km}$ depth, with a clear deepening toward
SE. A selected group of 33 well-constrained focal mechanisms indicates a minimum horizontal principal stress tensor $\left(\sigma_{3}\right)$ oriented 219 (Boncio et al., 1996). 
Boncio et al. (1998), interpreting all the available instrumental seismic data, propose that the Altotiberina Fault controls the location of the local seismicity, all concentrated in its hanging-wall, close and east of the branch-line with the Gubbio Fault. Consequently, the historical damaging earthquakes are located east of Gubbio Basin, where the Altotiberina Fault deepens (fig. 1). On the basis of the substantial agreement between the kinematics of the major active faults, the Quaternary tectonics, paleostress computations and the seismologic extensional tensor Boncio et al. (1996) suggest that the stress field in the area is constant at least since Upper Pleistocene.

These observations are not definitive in the understanding of the present activity of the Gubbio structure but, on the contrary, raise important questions about the true role of the Gubbio Fault in the seismogenesis of the region.

\section{Geomorphic evidence of active tectonics}

To analyze the geomorphic, recent tectonic and geologic evolution of the Gubbio Basin we performed a field survey focused on geologic mapping at 1:25000 scale, supported by 1:33000 scale aerial photos analyses (IGM, years 1955/1956, 1991 and 1994). We mapped drainage, erosional and terrace surfaces, scarps, peaks, saddles, sharp ridges, deep linear erosions, structural lineaments, faults, alluvial fans, etc. (fig. 6). At the same time we used digital cartographic data at a 1:5000 scale, provided by the Umbria region, to build a $5 \mathrm{~m}$ resolution DEM (Digital Elevation Model). By using a GIS program we geo-referenced all the data collected and performed morphometric analyses of the topography and of the drainage pattern. We used the GE.MI.NA. (1963) stratigraphic scheme as a reference for the classification of the continental units outcropping in the study area (fig. 2).

\subsection{Physiography}

The alluvial complex crops out over most of the Gubbio Basin (fig. 2). Its sedimentary facies has been interpreted as the final stage of the
Pleistocene lacustrine infill (GE.MI.NA., 1963). It is composed by low gradient alluvial fans that have been fed by transversal streams flowing through the carbonatic anticline from NE to SW (fig. 6). Four principal fans can be distinguished along the eastern side of the basin: one isolated is near Mocaiana village, while the other three coalesced north and south of Gubbio town. The alluvial complex, which hides the lower lacustrine sequence (GE.MI.NA., 1963; Giaquinto et al., 1991), appear to control the SW dip of the basin floor (fig. 7, cross sections 3 to 9). In general, the alluvial complex does not experience strong erosion, with the exception for the alluvial fan near Mocaiana, the northern part of which has been eroded by the Assino River (fig. 6). Moreover, the alluvial fan, just north of Gubbio (fig. 7, cross section 13), acts as local divide for the drainage basin (see Section 3.2.).

The Gubbio Basin is a $22 \times 4 \mathrm{~km}$, NWtrending elongated depression. The slopes bounding the basin exhibit a different morphology depending both on their lithology and structural setting. The basin floor lies at about $400 \mathrm{~m}$ a.s.l. whereas the eastern and western ranges reach elevations of about 950 and $650 \mathrm{~m}$ a.s.l., respectively.

The eastern flank of the basin has the steepest slope (fig. 7) and presents an important debris deposition at its foot. The declivity of its northern section shows a typical regularized slope replacement profile (Bartolini, 1992) with a homogeneous inclination of about $30^{\circ}$ (fig. 8 , cross sections 5 and 6). Differently, the southern part exhibits a higher inclination $\left(35^{\circ}\right)$ and profile irregularities, such as scarps, can be observed on the slope debris, but not in correspondence of the bedrock fault plane (fig. 8, cross sections 1, 2, 3 and 4). The eastern slope, carved by wide triangular facets also detectable from DEM (see inset of fig. 8), is modeled on back-dipping Jurassic-Oligocene bedding of the footwall formations. It represents the source of high-angle young fans developed over slope debris and older fans of the alluvial complex (fig. 6). This flank appears strongly controlled by the activity of the Gubbio fault and, because of the significant slip accommodated, only the eastern limb of the Gubbio anticline crops out. The resulting occurrence of strong erosional 


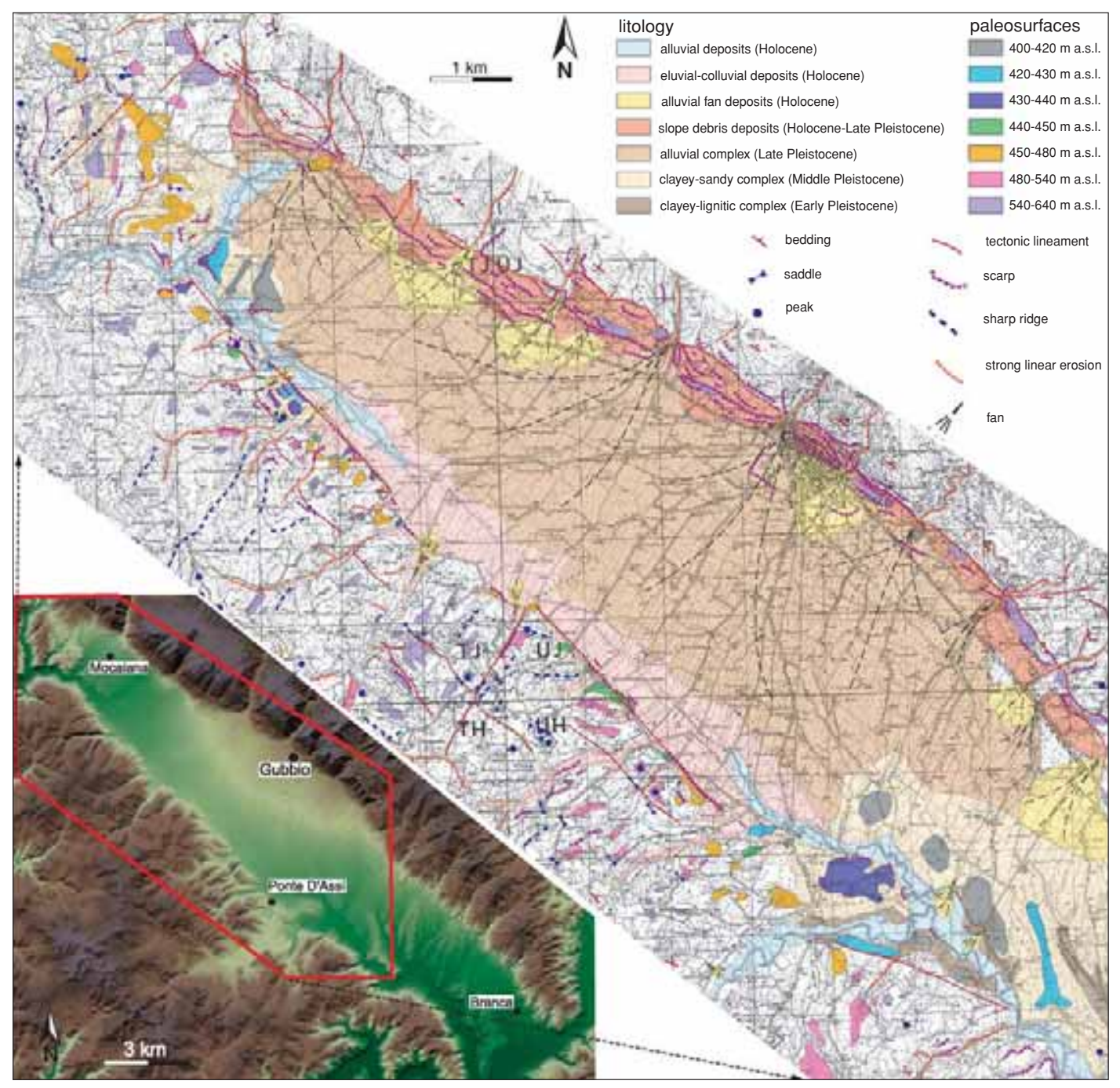

Fig. 6. Map of Quaternary geology and geomorphology of the northern and central portion of the Gubbio Basin from aerial photo and field survey. The lower left inset shows the location of the study area (see also dashed area in fig. 2) on the 5-m resolution DEM.

processes is testified by the larger amount of continental sediments, which buried most of the down-thrown anticline back-limb. We dated a paleosoil, found inside the slope debris deposits north of Gubbio by means of radiocarbon analysis (fig. $3 \mathrm{~b}$ for location), this yielded an age of 39 ky BP. Between Gubbio and Mocaiana (figs.
2 and $3 b$ ), where two sections of the fault overlap, this slope debris has the largest surface extension and reaches the highest elevations. To the northwest, the surface slope of these deposits is higher than their structural dip (about $15^{\circ}$ ) indicating that its dynamic development is predominantly governed by a strong erosional activ- 


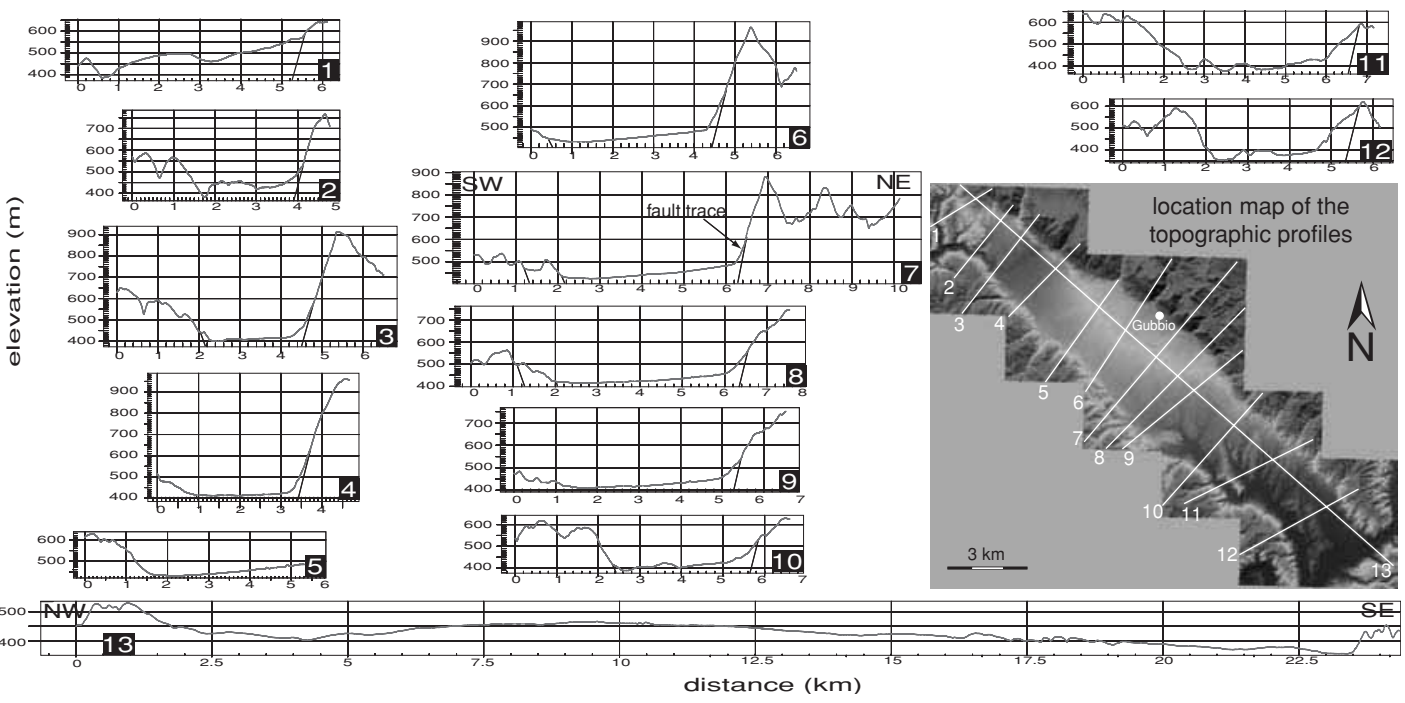

Fig. 7. Topographic profiles across and parallel to the Gubbio Basin performed by means of the $5 \mathrm{~m}$ resolution DEM. The position of the Gubbio Fault trace is shown in the profiles.

ity interpretable as due to the regional tectonic uplift or as caused by local lowering of the basal level. Anti-dip streams participate in the modeling of this slope by removing debris deposits and by forming minor entrenched Holocene alluvial fans (figs. 3b and 6). Sinuosity of the mountainpiedmont contact is quite high, typical of slopes controlled by low activity faults (Bull and McFadden, 1977).

An along strike comparison between the geologic displacement on the Gubbio Fault and the topographic throw (difference between the maximum elevations of the Gubbio anticline and the elevations of the basin floor, measured along transects perpendicular to the Gubbio Fault) is shown on fig. 4 (Collettini et al., 2003). The location of the two maximums does not coincide, suggesting that the differential erosion has a strong influence in the landscape evolution. It is also to be noted that the prePleistocene depocentre (Menichetti, 1992) is located exactly where the geologic displacement reaches its maximum. In conclusion, along this flank of the basin the action of the surface processes appears to be in strong competition and mostly prevailing over tectonics.
The western flank of the basin has a completely different morphologic expression with respect to the eastern one. It does not show any important folding structure and has low relief energy. In fact, at the contact mountain-piedmont only colluvial deposits and low gradient alluvial fans are found, as a consequence of the range consumption (fig. 6). The bedrock shows basinward, gently dipping beds, generally with oblique strike with respect to the contact bedrock/basin infill. Gravitational processes have a strong control on the landscape evolution, the bedrock being constituted by flysch deposits. In the field, relevant fault mirrors do not crop out, probably they are not preserved because of their rheology. In addition, the long-term deformation appears to be accommodated by minor tectonic structures. The competition of the landscape modeling with tectonics is minor and thus the potential for the preservation of surface evidence of recent faulting is higher. The mountain-piedmont junction is noticeably dissected, but the contact between the 15 and the 30 percent grades of the slope shows a clear straight NW-SE trend, typical of fault-controlled slopes. 


\subsection{Drainage network}

The complex drainage network of the Gubbio Basin is shown in fig. 9. It is formed by two secondary hydrographic networks, connected with the Assino and Chiascio rivers. These streams, located at the northern and southern end of the basin, respectively, flow perpendicularly to the NW-SE trending compressional structures. The whole Gubbio drainage basin has a watershed that does not follow the main elevations of the area, which coincides with the carbonatic structure but, anomalously, it runs always on the highest crests of the flysch formations (fig. 9). As a consequence the northeastern part of the Gubbio Basin watershed is peculiarly shifted to the east with respect of the carbonatic anticline and coincides with the Regional Divide. To the west the watershed is more irregular and enlarges north of Mt. Urbino.
In the northeastern part of the Gubbio drainage basin, a trellis water-network developed with a NE-SW and a NW-SE trending patterns (fig. 9). While the latter is organized in alongstrike valleys, emphasized by selective erosion, the NE-SW creeks fed the major fans of the alluvial complex, cutting perpendicularly the carbonatic structure. Some of these streams evolved in deep watergaps, which incised the slope, shaping smoothed triangular facets (see inset of fig. $8)$. On the contrary, in the western flank of the basin, composed by flysch formations, the drainage is organized as a dendritic water-network (fig. 9).

The Gubbio drainage network shows a peculiar diverging trend, where the main fan (fig. 6), close to the Gubbio town, acts as a water divide between the North Saonda Creek and the South Saonda Creek flowing NW-SE with opposite directions (fig. 9, anomaly d).
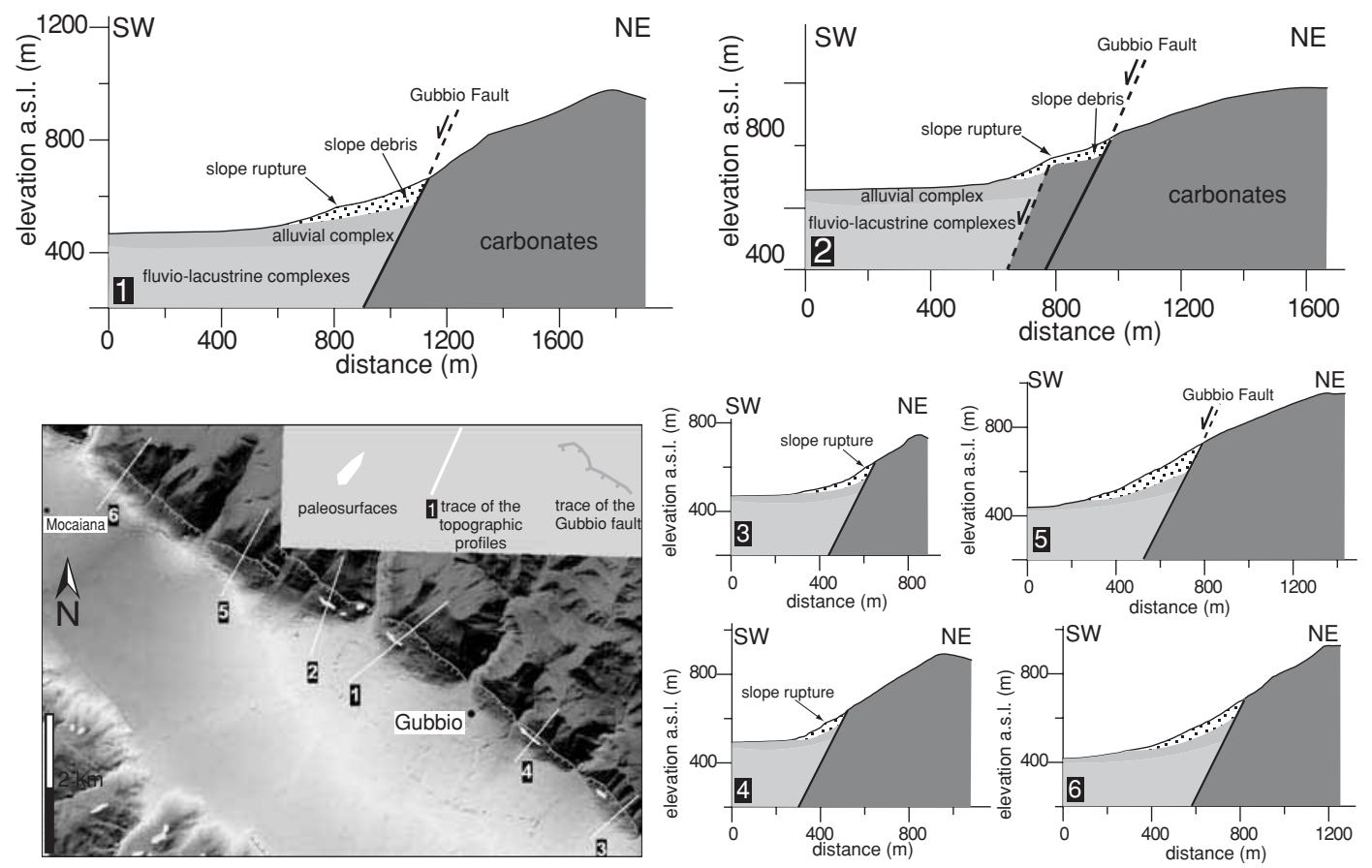

Fig. 8. Detailed topographic profiles, across the Gubbio Fault. All the profiles show the location of slope ruptures, the bedrock fault trace and a schematic geological setting. 


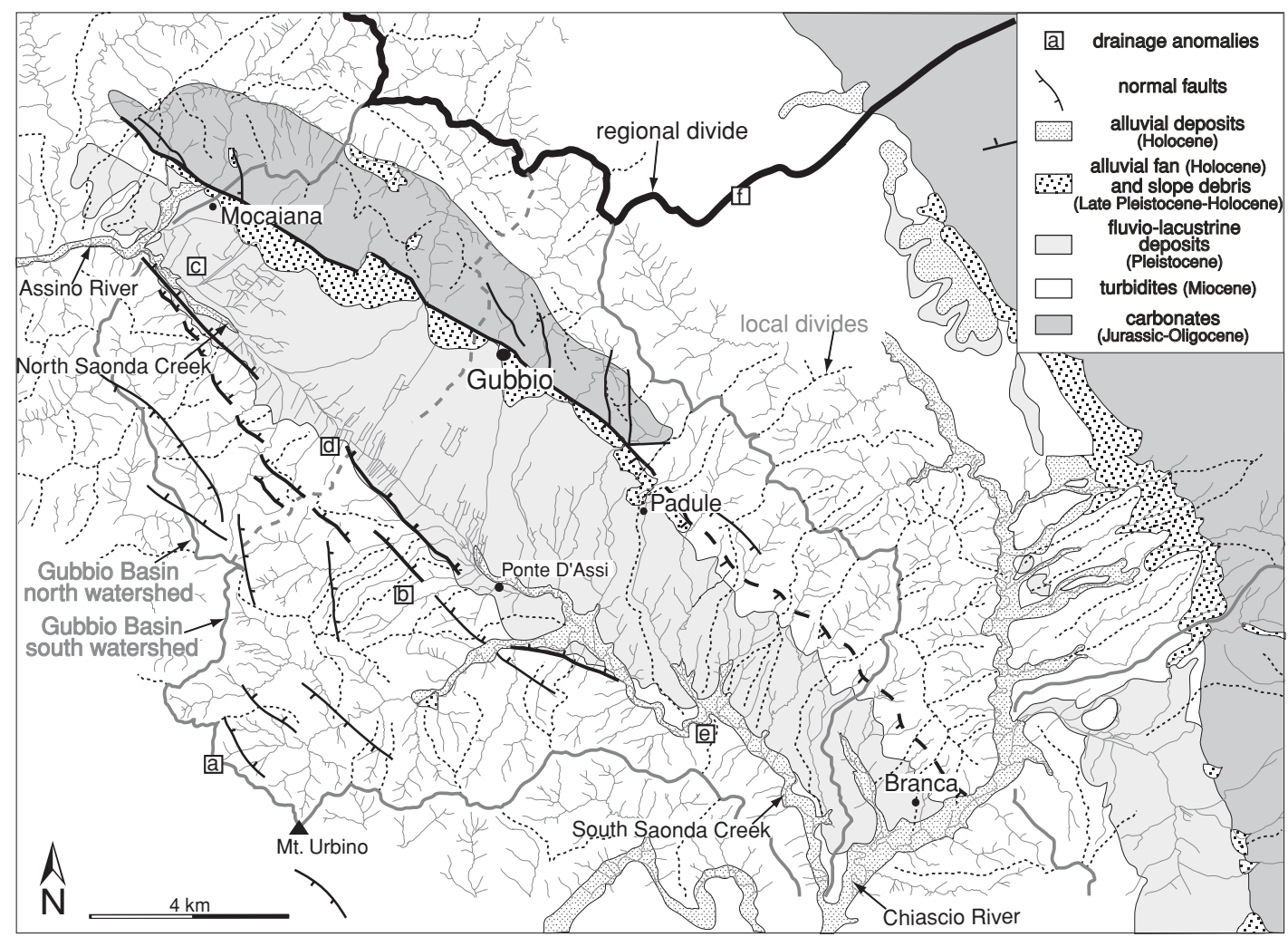

Fig. 9. Drainage map of the Gubbio area. Thick dashed line divides the Gubbio area in two smaller drainage basins: the North and the South Saonda creek basins. Simplified geology is reported.

These main creeks show a clear linearity, flow parallel to the maximum basin elongation, and are located close to its western flank. Thus they are in asymmetry with respect to the axis of the basin and also in disagreement with the prePleistocene depocentre (fig. 3a,b). This asymmetry may be explained with a progressive migration of the rivers westward as the fans prograded. However, the rivers linearity and low fan dip, coupled with the observation that the South Saonda Creek flows close to the western edge of the basin, even where large alluvial fans are not present, are suggestive of a tectonic control.

Within the Gubbio Basin, the South Saonda Creek incises the lacustrine sedimentary sequence up to the lowest units, both along the NE-SW gradient direction and perpendicular to it. On the contrary, the North Saonda Creek is less developed, in fact Middle Pleistocene deposits are incised only near the confluence with the Assino River and the alluvial complex is still well preserved. South of Mocaiana, the gentle geomorphology between two coalescent alluvial fans, deposited at the end of lacustrine cycle, presents a local convergence of drainage (fig. 9, anomaly c).

Most stream anomalies have been recognized in the southern part of the basin, where the South Saonda Creek appears to be left stepped and composed by two main sections, NWSE trending (fig. 9, anomaly e). South of Ponte D'Assi, where this creek reduces the amplitude of its Holocene deposition and assumes a degradational behavior, its sinuosity index 


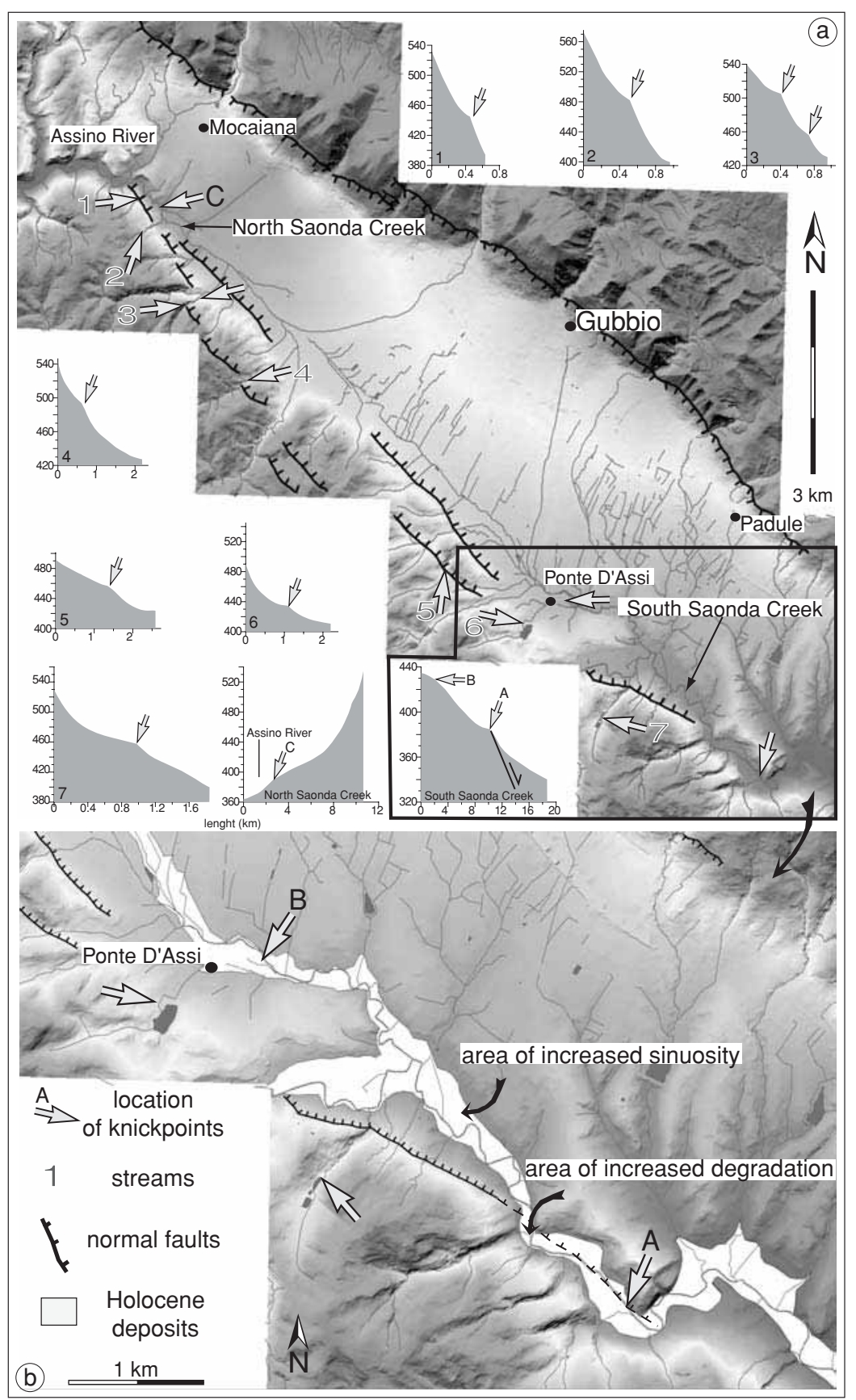

Fig. 10a,b. a) Longitudinal profiles of the western basin streams performed from $5 \mathrm{~m}$ resolution DEM with knick-points location; b) detail of the South Saonda Creek showing changing behavior running from the footwall to the hangingwall of a fault section. 
decreases from 1.6 to 1.1 (fig. 10b). Two knick points have been detected along the South Saonda Creek (fig. 10a), one is located near Ponte d'Assi (knick point B) and seems to be related to regressive erosion, while the southernmost (knick point A), being in line with a tectonic lineament (mapped through aerial photos interpretation), has been tentatively interpreted as controlled by the activity of the structure. In the same area, west of Ponte D'Assi, the hierarchic organization of several NE-SW oriented creeks may suggest, again, a recent tectonic control on the development of the drainage network.

In the northern part of the Gubbio Basin, the longitudinal profile traced along the North Saonda Creek shows the presence of a knick point at the northern threshold of the Gubbio plain (fig. 10a, knick point $\mathrm{C}$ ) and consequently testifies the capture of the North Saonda Creek by the Assino River. The location of this capture through a threshold located in an area of local topographic high, induced us to consider a possible tectonic control by a NW-SE trending lineament bounding the northwest side of the basin (fig. 6). Similar analyses have been performed along the tributaries of the North and South Saonda creeks. Several of these drainages, incised on the flysch deposits of the western side of the basin, show non-equilibrium profiles and knick points, which align in a NW-SE direction, this is also suggestive of tectonic control (fig. 10a)

\subsection{Paleosurfaces}

Within the Gubbio Basin we have mapped several relict surfaces (fig. 6), which are evidence of paleolandscapes; these include both erosional surfaces, carved on the local bedrock, and lacustrine depositional terraces. The majority of these surfaces are found in the northwestern part of the basin at different elevations. Because of the lack of direct dating, we attempt their analysis by sorting them by height in seven groups, which are reported in the fig. 6 with different colors. A correlation among all this surfaces being very difficult, we looked for their possible relations with other geomor- phic elements such as scarps, lineaments and streams. The majority of these surfaces cannot be unequivocally attributed to variations of the Pleistocene lake level or to recent tectonic dislocations.

Along the western slope of the basin it is possible to observe a large number of surfaces, widely distributed, and, in particular, the bestpreserved sequence is located near Ponte d'Assi (fig. 6). Differently, the eastern slope of the basin does not show any comparable sequence of surfaces nor indented on the slope debris or on the alluvial complex. A series of topographic profiles, both parallel and perpendicular to the western basin flank, are shown in figs. 11 and $12 \mathrm{a}-\mathrm{d}$ to evidence the relative height of the surfaces. At the northern termination of the basin, the principal surfaces, both erosional and depositional, progressively decrease in elevation toward south. In fact, the highest depositional surfaces, belonging to the sandy-clay complex, lie at a maximum height of 540-560 m a.s.l. in the northern area whereas, appear, at an elevation of 450-480 m a.s.l. near Ponte d'Assi (fig. 11, cross-section 5 and 6; fig. 12a-d, crosssection 12).

In order to analyze the distribution and relation of the different surfaces with respect to the present topography, we simulated a draining sequence of the Gubbio Basin by subsequently setting the lake level at 535, 480, 440 and $420 \mathrm{~m}$ a.s.l. (fig. 15a-f). When we fix the lake level at the highest elevation (535 m a.s.l.) (fig. 13) only few surfaces appears. At the northern termination of the basin, depositional surfaces topping the lacustrine sequence can be seen where the geologic throw of the Gubbio Fault tapers to zero (figs. 4 and 7, between cross sections 1 and 2). Along the central part of the eastern flank of the basin, some NW-SE elongated small surfaces, indented on the debris deposit, show up. Taking into account their position, shape and substratum, these surfaces have been interpreted as slope ruptures, probably related to secondary splays of the Gubbio Fault (fig. 3b). On the western side of the basin, surfaces carved in bedrock up to $640 \mathrm{~m}$ a.s.l. determine a staircase topographic profile about $3 \mathrm{~km} \mathrm{NW}$ of Ponte D'Assi and present their outer edges bounded by tectonic lineaments. The western flank 


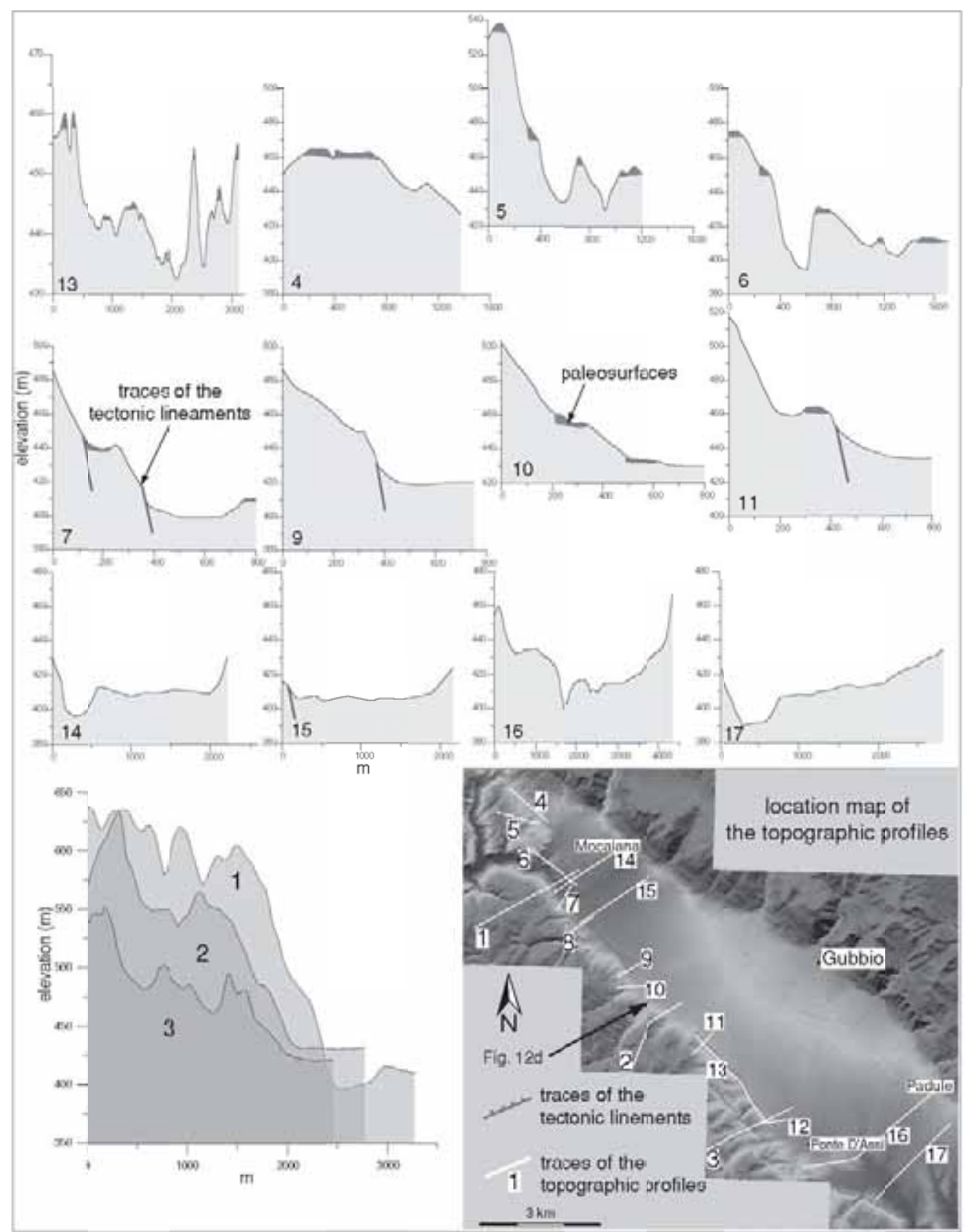

Fig. 11. Detailed topographic profiles, across and along the western slope of the basin, performed from 5-m resolution DEM. The location of the main paleosurfaces (dark gray) together with the traces of the observed tectonic lineament is shown. Profile 1,2 and 3 are shown in overlap to highlight the elevation decrease of the paleosurfaces between north and south. 

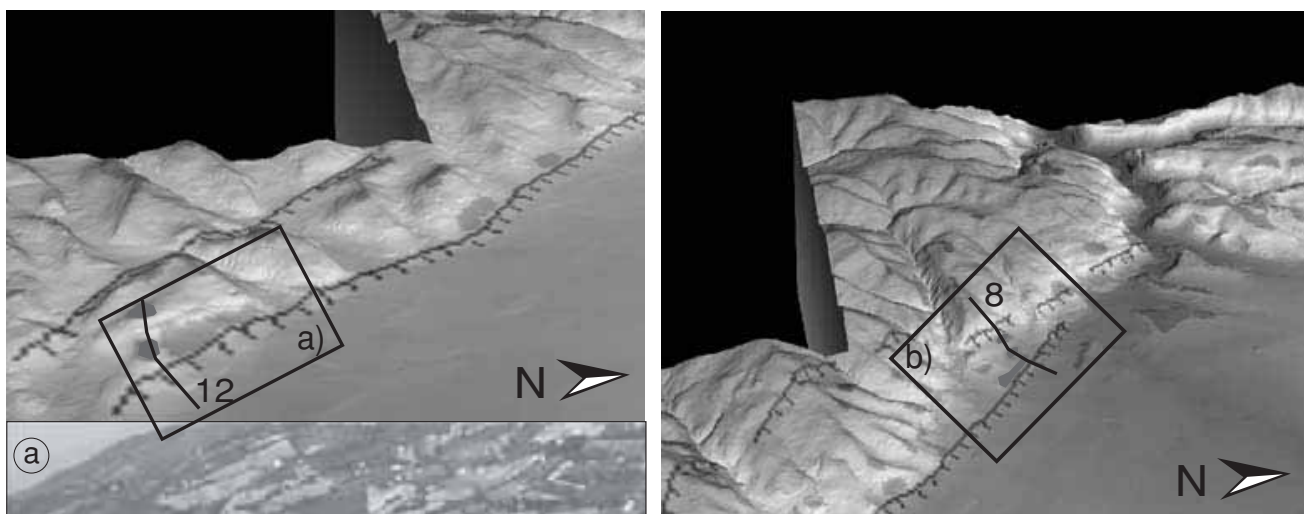

(a)
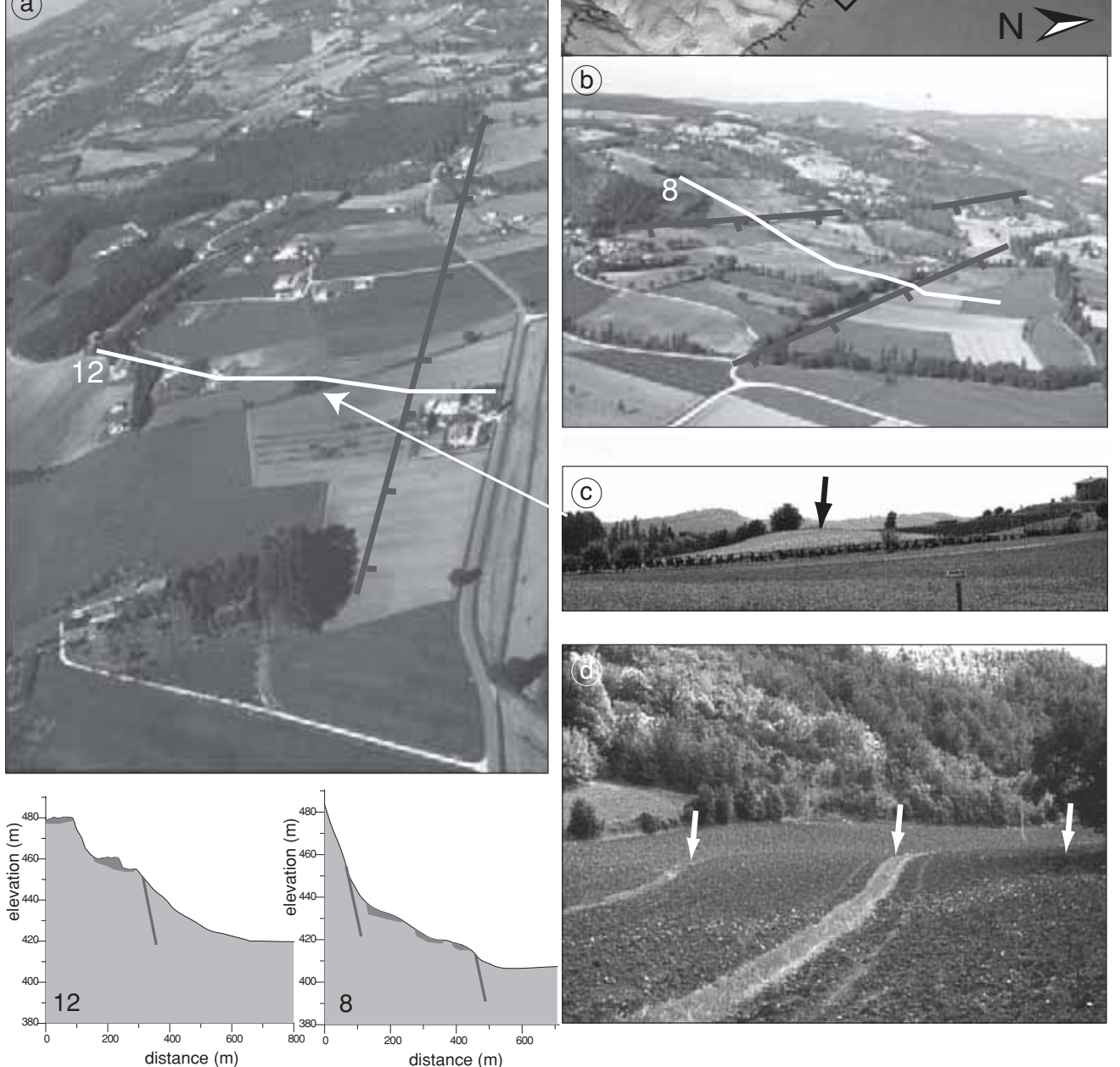

Fig. 12a-d. 3D view of some paleosurfaces and scarps, from $5 \mathrm{~m}$ resolution DEM, along with their aerial photograph view (a and b) and their topographic profiles (12 and 8). c) Landscape photograph detail of a paleosurface of fig. 12a. d) Landscape photograph of a scarp crossing a recent alluvial fan (see fig. 11 for the location). 


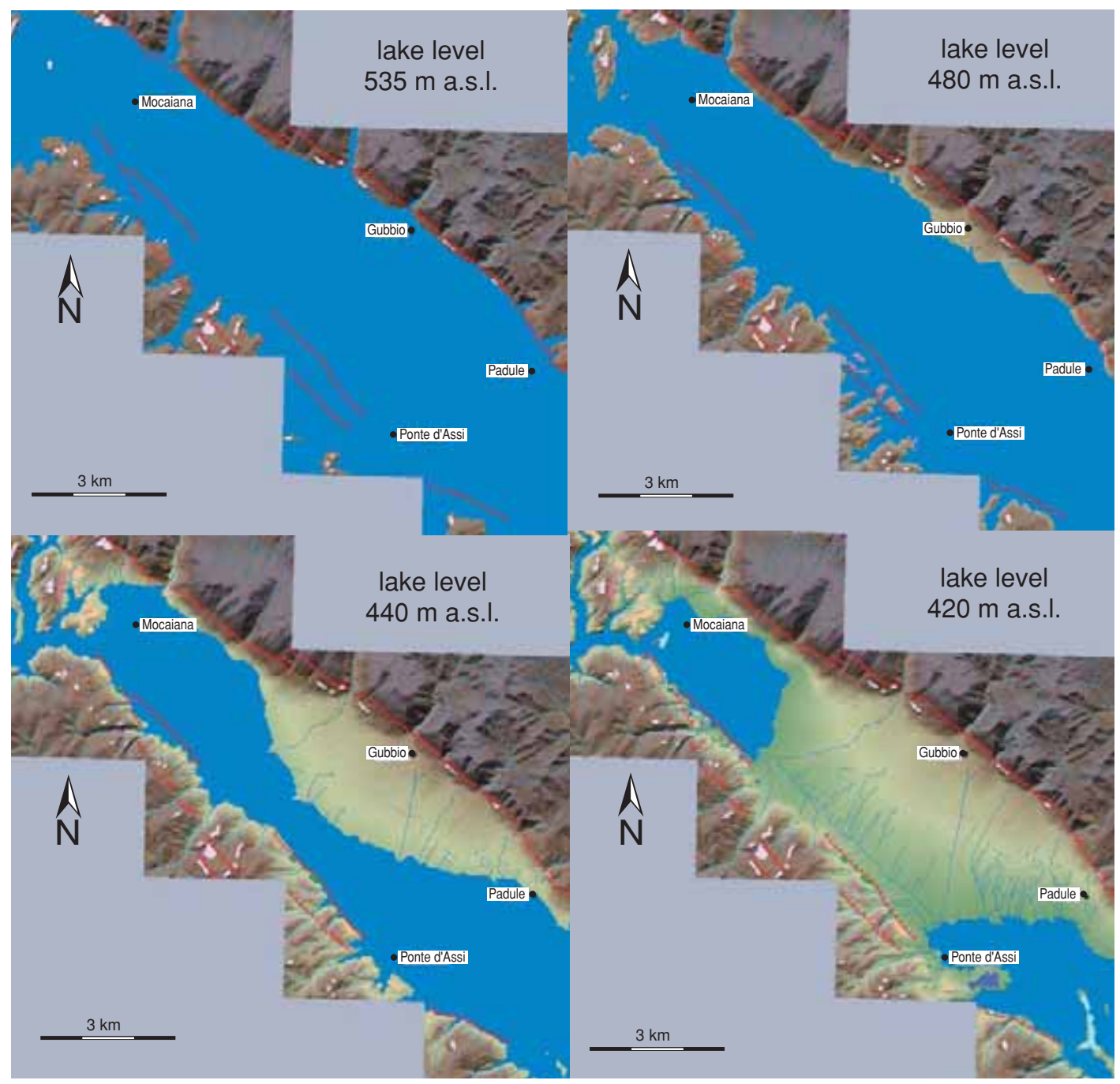

Fig. 13. Draining sequence simulation of the Gubbio Basin obtained by subsequently setting the lake level at $535,480,440$ and $420 \mathrm{~m}$ a.s.l. See legend of fig. 6 for the reported paleosurfaces. Topographic base acquired from 5-m resolution DEM.

assumes an almost rectilinear, NW-SE trending attitude only when we decrease the water level at $480 \mathrm{~m}$ a.s.l.; conversely, the eastern side appears strongly controlled by the Gubbio Fault since the earlier stages (fig. 13). Going on with the draining sequence simulation up to $420 \mathrm{~m}$ a.s.1., we observed: 1) the presence of several sur- faces at the northern end of the basin, mainly on lacustrine deposits; 2) a discontinuous distribution of surfaces, both on bedrock and continental deposits, often organized as staircase flats included within parallel tectonic lineaments along the western flank; 3) the absence of analogous surface sequence along the 
eastern side, where alluvial deposition dominates. We also noted that the lower surfaces along the western slope of the basin are formed only on Pleistocene continental deposits, with the outer edge scarps generally parallel to the North and South Saonda creek.

\subsection{Morphotectonic observations}

Morphostructures such as tectonic lineaments, escarpments and bedrock fault planes have been mapped in the Gubbio Basin (fig. 6).

Different authors suggested the existence of active tectonic in the Gubbio Basin. Boncio et al. (1996) describe deformed slope debris directly in contact with the fault plane, at a location about one kilometer SE of the town of Gubbio. However, we did not notice any clear deformation possibly linked to recent activation of the Gubbio Fault at the site. Selvaggi and Sylos Labini (1989) observed a $2 \mathrm{~km}$ long scarplet displacing the deposits of the Gubbio fans. Archeological literature (Branconi and Manconi, 1982-1983) describes in this site a buried ancient Roman wall. Although the published evidence appears to be highly questionable, the signature of active tectonic processes in the area can be found through detailed analysis.

Along the eastern flank of the basin, we noticed that the Gubbio Fault Zone exhibits a clear geometric segmentation with a left step of the fault plane exposed between Gubbio and Mocaiana. The same zone of stepover is also recognized at depth, from the reconstruction of the bedrock/basin infill contact (Menichetti, 1992). As a whole, the Gubbio Fault Zone has a concave shape with dip directions from N240 to $\mathrm{N} 220^{\circ}$ moving northward. Topographic profiles show several irregularities on the slope debris identified as morphological scarps (fig. 8, cross sections 1, 2, 3 and 4). Even though part of them may be related to human activities, it is interesting to note that they are often rectilinear and aligned for a maximum length of two kilometers. Calcareous bedrock has been exhumed from the debris cover in the hangingwall of the outcropping Gubbio Fault, due to erosion and to extensive quarrying. Such bedrock appears to be located between slope ruptures and the bedrock fault planes, suggesting the existence of at least two main fault splays below the continental deposits (fig. 3b). At the northeastern edge of the basin, several shear structures, affecting the debris polycyclic depositional horizons, can be recognized on the walls of large artificial cuts. One of these cuts was studied in detail (1/20 scale) (fig. 3b for location). In fig. $14 \mathrm{a}, \mathrm{b}$, vertically re-oriented clasts and offset, of the order of few centimeters, of distinct layers indicate the presence of small NWtrending and SW dipping normal faults. Considering the steep slope related to this side of the basin, the discrimination between tectonic and gravitational origin of these structures remains unclear.

Along the western flank of the basin two new morphologic lineaments have been recognized (fig. 6). These two NW-SE striking lineaments are parallel. The western one is defined by several linear sections, arranged in a right stepping system, and is entirely located on bedrock. Several geomorphological features contribute to the identification of this structure: saddles, tops, escarpments and staircase surfaces included within parallel sections (fig. 6). The eastern lineament is located at the bottom of the slope and is identified by aligned scarps, both in colluvium and bedrock, and by paleosurface outer edges (fig. 11, topographic profiles 7, 9 and 11). Although taking in consideration the possibility for a fluvial-lacustrine origin for the alignment of these outer edges, we propose a tectonic origin, mainly because of a clear elevation change in their along strike topographic profile (fig.11, topographic profile 13). In general, the two lineaments have been recognized and mapped in detail for more than $15 \mathrm{~km}$, from the northern termination of the basin to the south. These lineaments are interpreted as the expression of an east-dipping normal fault, which describe, as a whole, a concave geometry mirroring that of the Gubbio Fault (fig. 2).

\subsection{Defining active faults in the Gubbio Basin}

The Gubbio Basin is clearly bounded to the east by the prominent NW-striking, SW-dip- 

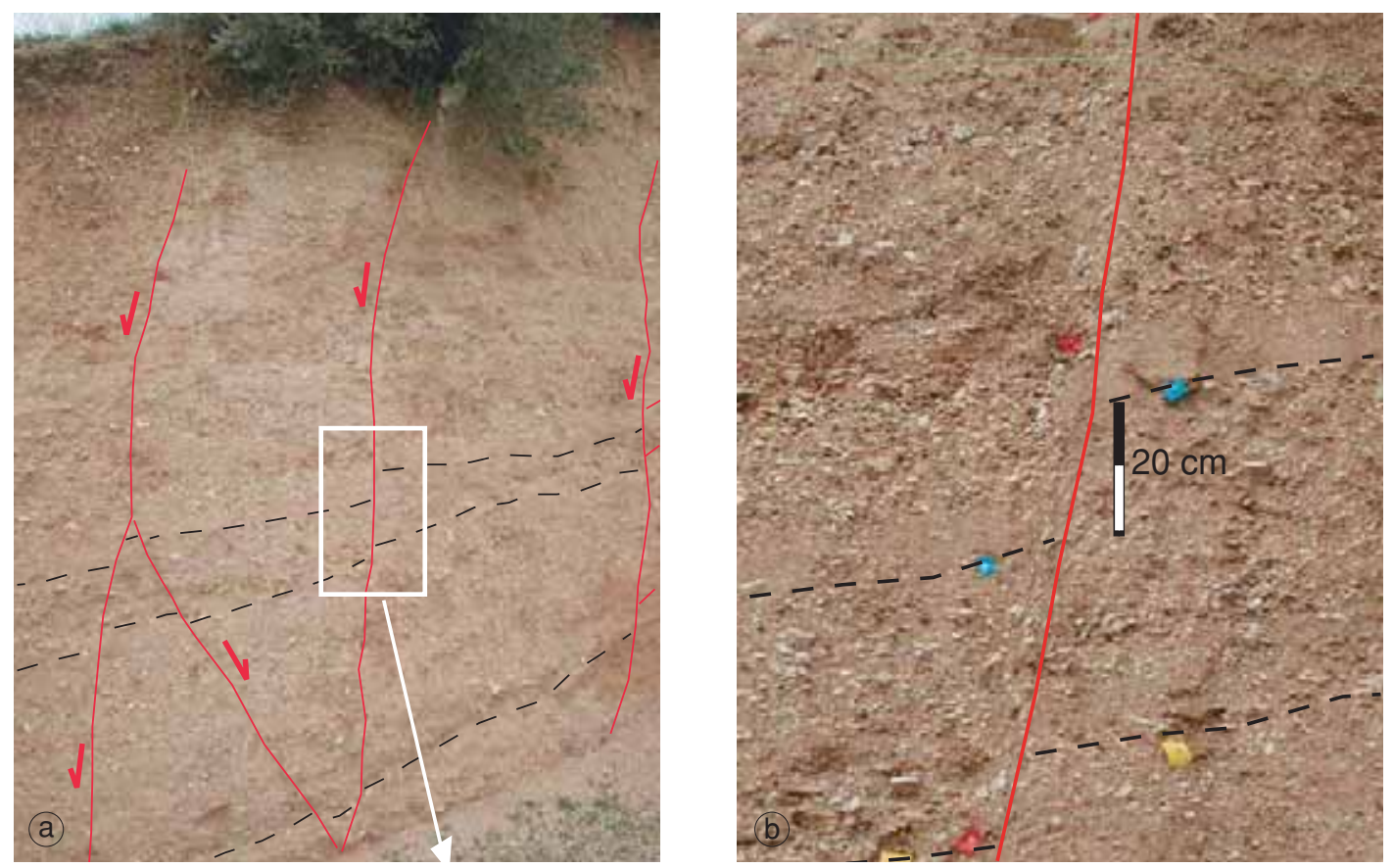

Fig. 14a,b. a) Photo of the NW wall of the artificial cut affecting the slope debris near the Gubbio Fault. In figure are highlighted normal faults (continuous line) and main depositional horizon (dot line); b) detail showing the re-oriented clasts and the offset amount.

ping, about $22 \mathrm{~km}$ long Gubbio normal fault. This structure is clearly responsible for the basin inception and for a maximum total throw of the carbonatic multilayer (Jurassic-Oligocene) of about $2500 \mathrm{~m}$ (Mirabella, 2003). The detailed reconstruction of the Gubbio Fault isobaths by Barchi et al. (2000) shows an abrupt change in the plane dip from $50^{\circ}$ to $20^{\circ}$ below $3.5 \mathrm{~km}$. All the geomorphic elements used to discuss the Gubbio Fault activity should refer to the steeper and more superficial part of the fault: no obvious geomorphic evidence for the characterization of the low-angle part of the fault exists. Therefore, in the following we will discuss the Gubbio Fault as composed of a high and a low-angle portion.

Simple topographic profiling across the fault trace shows a gently dipping regularized profile with the section on the calcareous bedrock having a grade similar to that built on de- bris deposits (fig. 8). Even if the Gubbio Fault strongly controls the eastern flank of the basin, separating two different lithological sectors, no evidence for a recent important activation of the bedrock fault plane has been observed. The predominance of the erosional and depositional processes with respect to tectonic activity along the main Gubbio Fault Plane is shown by the presence of young entrenched alluvial fans (figs. $3 b$ and 6) and by the misfit between the curves of topographic and geologic throw along the fault strike (fig. 4). Here differential erosion dominates due to the presence of the pre-existing carbonatic anticline. However, field and airphoto investigations of the debris deposits along the fault hangingwall are suggestive of minor recent displacements located west of the main bedrock plane. The presence of slope ruptures and elongated small suspended benches (fig. 8, cross section 2), associated with small 
normal faults affecting slope deposits (fig. $14 \mathrm{a}, \mathrm{b})$, and the unconformity of the debris layers dip with respect to the present erosional surface slope, suggest the existence of two parallel fault splays located about $500 \mathrm{~m}$ west of the Gubbio Fault between Gubbio and Mocaiana (fig. 3b). Some of these variations of the topographic gradient represent landslide crowns, although their linearity and continuity (up to $1.5 \mathrm{~km}$ ) would support a tectonic origin. The clear predominance of the erosional processes over tectonics, partially controlled by the Apennines regional uplift (Doglioni et al., 1998), indicates low or negligible rates of tectonic activity of the high-angle Gubbio Fault.

The activity of the low-angle portion of the Gubbio Fault can be inferred on the basis of the location of the April 29, 1984 earthquake. The main shock location (fig. 5) is close to the branch line of the Gubbio Fault with the Altotiberina Fault (see inset in fig. 1). The CMT solution for the mainshock (Dziewonski et al., 1985) indicates the low-angle Gubbio Fault as the probable seismogenic source.

The Gubbio Basin is the long-term evidence of the activity of a $c a .22 \mathrm{~km}$ long fault. It is well known that geometry and size of a fault together with its slip amount and distribution, are the major factors controlling the evolution, length, and depth of a fault related basin, coupled with the regional uplift context. With a fault of a such length, which produced $\sim 2000 \mathrm{~m}$ of displacement, and assuming that both sections of the Gubbio Fault (high and low-angle) were active simultaneously, we would expect a fault related basin 8 to $10 \mathrm{~km}$ wide. This is in clear contrast with the present setting of the basin which is peculiarly narrow, not exceeding a width of $4 \mathrm{~km}$. Our investigations highlighted that the western flank, although without an associated impressive topographic relief, exhibits a peculiar geomorphology which suggest a tectonic control on the basin. Looking in detail, two mains, NW- trending, parallel lineaments appear to dominate all along this flank (fig. 6). The westernmost is clearly arranged in a right stepping system with several creeks, flowing across it, showing aligned knick-points suggesting normal faulting with east side down (fig. $10 \mathrm{a}, \mathrm{b})$. The second lineament is located close to the contact with the basin infill (figs. 6 and 11), where it affects both Miocene and Quaternary deposits. This lineament is composed by a series of aligned scarps, bordering several fluvial-lacustrine surfaces at different elevation and intersecting recent alluvial fans (fig. 12d). The interpretation of these lineaments as E-dipping normal faults is supported also by the location and linearity of the North and South Saonda creeks, flowing close and parallel to the basin western flank.

Thus, we propose that a normal fault antithetic to the Gubbio Fault exists along the western side of this basin, close to the contact bedrock/infill. This antithetic fault has an average strike parallel to the Gubbio Fault and may explain the reduced $4 \mathrm{~km}$ width of the basin.

\section{Modeling of faults in relation with landscape evolution}

In the previous sections we suggested that the present setting of the Gubbio Basin is the result of long-term activity of two W-dipping normal fault (a low and high-angle sections confined between depth 6 and $3.5 \mathrm{~km}$ and above 3.5 $\mathrm{km}$, respectively) and of a secondary antithetic high-angle normal fault located above $2.8 \mathrm{~km}$ (fig. 15b). To test this hypothesis with an independent approach, we tried to verify the influence of these fault sections on the landscape evolution of the Gubbio Basin. The idea is to compare the deformation expected to be produced at the surface by each fault, or by a combination of faults, with the observed basin setting. To achieve this goal we modeled the expected deformations by using a code, based on standard dislocation theory developed by Ward and Valensise (1989). Consequently our calculations assume uniform slip on planar, rectangular faults embedded in elastic half-space.

To establish the fault parameters of our model, we adopted for the low and high-angle portions of the Gubbio Fault a simplified fault geometry (fig. 15b, faults 1 and 2), derived from the detailed reconstruction of the fault isobaths (Barchi et al., 2000). To determine the fault length of the antithetic structure, we used the data derived from field survey and air photo 

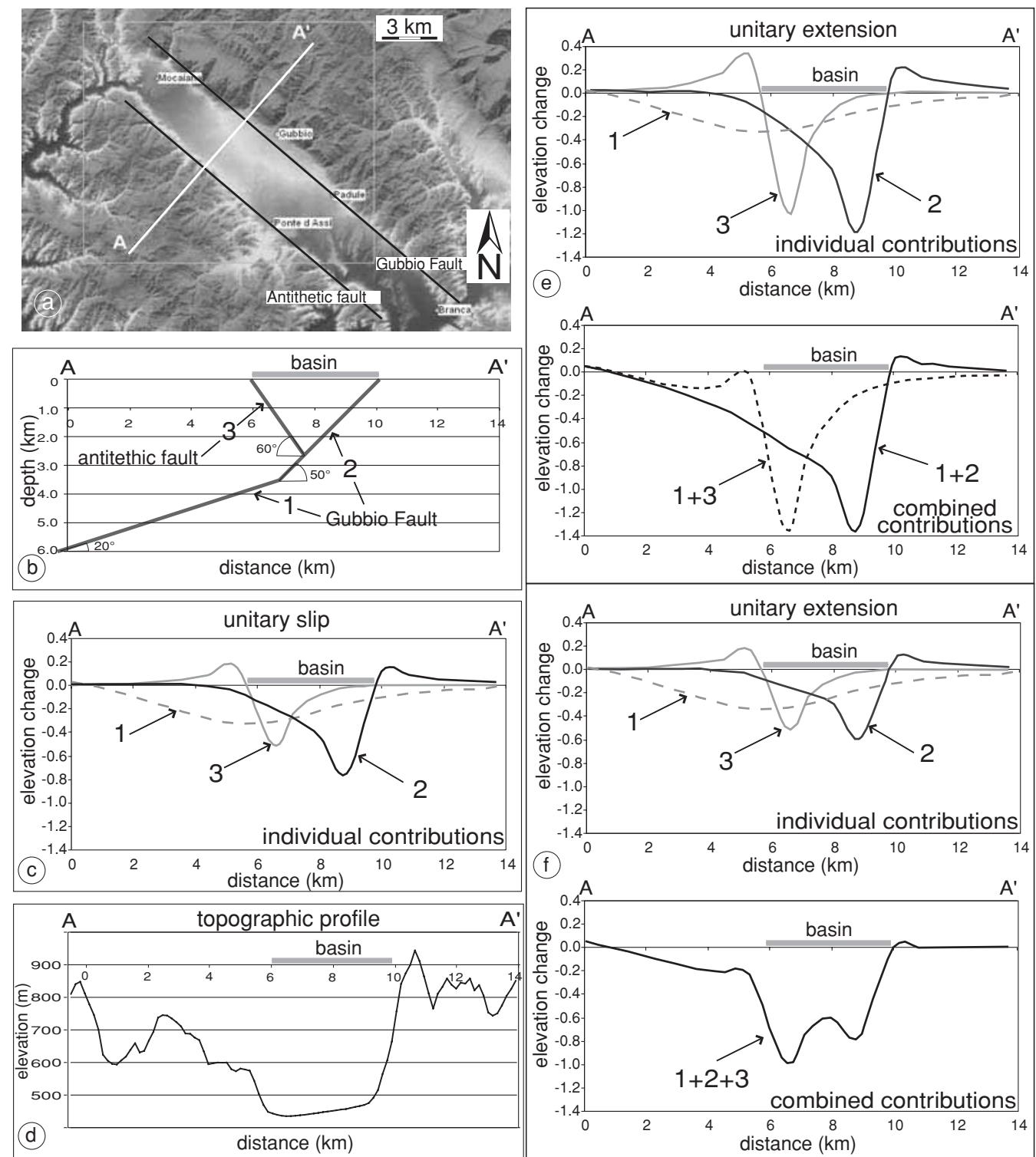

Fig. 15a-f. Modeled elevation changes due the activity of the two sections of the Gubbio Fault and its antithetic structure. a) Location map of the modeled transect. b) Sketch of the faults geometry adopted. c) Individual contributions of the faults, assuming a unitary slip for each of them. d) Topographic profile along the modeled transect. e) Individual and combined contributions of the fault sections. Applying a unitary horizontal extension, NESW oriented, and assuming faults 2 and 3 accommodate alternatively the extension. Combination of faults 1 and 2 or faults 1 and 3 is shown in the lower part. f) Individual and combined contributions of the fault sections applying a unitary horizontal extension, NE-SW oriented, assuming the three faults work simultaneously. Each fault 2 and 3 has to accommodate half of the unitary extension. The combination of the three sections seems to fit well the topographic setting of the basin. 
interpretation assuming a constant $60^{\circ}$ dip down to the intersection with fault 2 to obtain its width (fig.15b, fault 3). For faults 2 and 3, we assume they are both surface-breaking and with a pure normal dip slip movement. Thus, we adopted a length of $22 \mathrm{~km}$ and a total width of $11.5 \mathrm{~km}$ for the two portions of the Gubbio Fault, a length of $18 \mathrm{~km}$ and a width of $2.8 \mathrm{~km}$ for the antithetic fault (fig. 15b, fault 3 ) and a general strike of $130^{\circ}$. All the elevation changes obtained by the dislocation modeling are calculated along the same transect (fig. 15a) for which a topographic profile is also plotted in fig. $16 \mathrm{~d}$. In the following, on the basis of our previous discussion, we consider that the lowangle portion of the Gubbio Fault (fig. 15b fault 1 ) is definitely active.

In order to test the role played by the geometric parameters of the modeled faults, we assigned to each fault the same unitary slip (fig. $15 \mathrm{c})$, being aware of the fact that this is not a realistic model for their long-term activity. From this model it is possible to note that: fault 1 generates a gentle, almost symmetric wide signal at the surface with its maximum subsidence in correspondence with the western edge of the basin; fault 2 produces an asymmetric sharp depression, about $6 \mathrm{~km}$ wide deepest in the eastern part of the basin; fault 3 produces an asymmetric sharp depression, deepest in the western part of the basin, the only completely confined within the basin. The location of the antithetic fault in the area of maximum subsidence produced by fault 1 , could be interpreted as the consequence of the deformation pattern resulting from the activity of fault 1 .

In order to make the expected elevation changes more realistic and because of the lack of direct measurements of extension across the area, we apply a unitary horizontal NE-SW extension on the system (fig. 15e,f) with fault 1 always active. In particular, in the model shown in fig. $15 \mathrm{e}$, we assume that the whole crustal extension above $3.5 \mathrm{~km}$ is accommodated only by one of the high-angle faults: thus only by fault 2 or by fault 3 . Whereas, in fig. $15 f$ faults 2 and 3 are active simultaneously accommodating half of the extension each. We are aware of the fact that probably this is a reasonable model only for the short-term activity of these faults.
An important implication of this test is that, summing the contribution of fault 1 alternatively with that of faults 2 or 3 in fig. $15 \mathrm{e}$, no satisfactory match with the basin setting is found. In fact, looking in fig. 15e at the combined contribution of faults 1 and 2 (forming the whole Gubbio Fault), we remark that the width of the modeled depression is quite larger with respect to the actual one (fig. 15d), and that the resulting asymmetry toward NE is in disagreement with the present drainage network within the basin, being clearly asymmetric toward the SW (fig. 9). Only the gentle dip toward NE of the continental deposits filling the basin (GE.MI.NA., 1963; Menichetti, 1992) seems to fit this model. On the other hand, the deformation distribution produced by modeling the combination of faults 1 and 3 (even if this setting is mechanically unlike) in fig. $15 \mathrm{e}$, shows a better fit with the basin width, linearity, and position of the North and South Saonda creeks, but is in strong contrast with the basin Quaternary sedimentary infill geometry (GE.MI.NA., 1963; Menichetti, 1992).

The lack of fit of the model shown in fig. 15e, which assumes only one of the faults 2 or 3 to be active along with fault 1 , and the geomorphic results discussed above, highlights the need for a combined contribution of the three faults in a graben-like setting (fig. 15f). An immediate consequence of this test is that the relative importance of the signal produced by fault 1 at the surface increases. We can also clearly note how the actual basin width is in good agreement with the modeled one (fig. 15d,f). Moreover, the overall shape of the computed elevation changes for the three faults combination (fig. 15f) is well comparable with the topography as well as with the prePleistocene basement shape according to Menichetti (1992) (fig. 3a). Finally, the fig. $15 \mathrm{f}$ model would fit better also the gentle dip of the basin infill deposits (fig. 3a) and admits some complexity in the near fault (e.g., high dip angle of the clayey-lignitic basal complex, GE.MI.NA., 1963).

\subsection{The Gubbio Fault System}

We have concluded that three main fault sections can be imaged in the Gubbio Basin, however, no unequivocal data exist to place some 
constraints on the age of activity of the individual fault sections, nor on their slip rates even on a relative basis. For the Gubbio Fault the authors (Selvaggi et al., 1989; Menichetti, 1992) set an inception of the activity between Late Pliocene and Early Pleistocene. During this period a maximum throw of $2500 \mathrm{~m}$ (Mirabella, 2003) has been accumulated, which would translate to a maximum slip rate higher than $1.4 \mathrm{~mm} / \mathrm{yr}$.

No constraints for the antithetic fault (fault 3) age of inception exist. The long-term evidence of this fault does not suggest an activity lasting since Early Pleistocene and producing kilometric displacement like the Gubbio Fault. The fact that the antithetic fault should have a smaller role than the Gubbio Fault in the basin development can be also inferred by comparing figs. $15 \mathrm{f}$ with $15 \mathrm{~d}$ and $3 \mathrm{a}$. We can notice a discrepancy between the modeling, where faults 2 and 3 are given the same weight (i.e. each accommodating the same amount of extension) and the present basin setting. To obtain a better fit we should reduce in the model the role of the antithetic fault with respect to the Gubbio Fault. It is hard to define whether this minor role of the antithetic fault is due to its lower slip rate, its more recent activation, or by a combination of these two. Even though the antithetic fault has had a minor role in the basin development, at present this appears to be the fault section most effective in producing a landscape signature and thus, to be considered active.

On the basis of the dislocation modeling we have argued that the combined activity of the two sections of the Gubbio Fault and its antithetic, is needed to explain the present setting of the Gubbio Basin (fig. 15f). However, we have also to consider erosion, driven by the regional uplift, as an important contributor to the present basin shape. The rates of uplift of the Apennines are expected to be as much as $1 \mathrm{~mm} / \mathrm{yr}$ (Doglioni et al., 1998); if these exceed the rate of subsidence in the basin, sedimentation in the hangingwall would not probably be enough to compensate the tectonic offset. At present, both footwall and hangingwall undergo erosion and is possible that sedimentation was never able to entirely fill the basin. However, this does not seem to be enough to assume the basin narrowness could be derived only by the activity of the
Gubbio Fault (fig. 15e, faults 1 and 2). In fact, the western edge of the basin is linear and not shaped according the distribution of displacement on the Gubbio Fault (wider in correspondence of the maximum throws).

Summarizing, on the assumption that the low-angle Gubbio Fault is the main active fault in the area below a depth of $3.5 \mathrm{~km}$, it is still unclear if today the antithetic fault takes over most of the extension across the upper few kilometers of crust, with an essentially inactive highangle Gubbio Fault, or if this latter is active too. The short-term geomorphic signal seems to suggest the Gubbio Fault to slip at a very low rate or to be inactive, whereas the antithetic fault to lead the present landscape evolution of the area. On the other hand, the maximum slip rates inferred for the Gubbio Fault ( $>1.4$ $\mathrm{mm} / \mathrm{yr}$ ) on its long-term activity appear to be too high in relation to its poor present geomorphic signature even in consideration of the expected erosional rates for the area. This clear discrepancy points out that the Gubbio Fault activity changed through time, allowing at an unknown time the inception of the activity of the antithetic fault.

\section{Seismogenic sources of the Gubbio Basin}

Based on the considerations discussed in the previous sections we conclude that the Gubbio Basin contains active and potentially seismogenic faults. However, the extent of the Gubbio Fault is quite large with respect to the presumable rupture length of the 1984 earthquake $\left(M_{S}\right.$ 5.3). At the same time, geomorphic data from the basin and the long-term evidence for Pleistocene fault activity do not suggests the existence of permanent fault boundaries.

The Database of Potential Seismogenic Sources for Earthquakes Larger than $M 5.5$ in Italy (Valensise and Pantosti, 2001b) proposed a preliminary scheme for the seismogenic sources of the Gubbio area based on available literature. The new data and considerations presented in this work allow us to propose an updated version of this scheme.

In the previous sections, we defined the Gubbio Fault System as formed by three $130^{\circ}$ - 
striking normal fault sections: a W-dipping, low-angle fault located below $3.5 \mathrm{~km}$ depth and two high-angle faults arranged in a graben-like setting located above $3.5 \mathrm{~km}$ depth (fig. 15b). This structure is limited by sharp northern and southern boundaries which limit its length to about $22 \mathrm{~km}$. The northern boundary is set on the basis of: a) the position of the northern tip of the Gubbio Fault as shown by geophysical data (fig. 4); b) the northern end of the basin as defined by the presence of several depositional paleosurfaces located at the highest elevation within the basin (fig. 6), indicating an area of lower subsidence typical of a fault tip, and

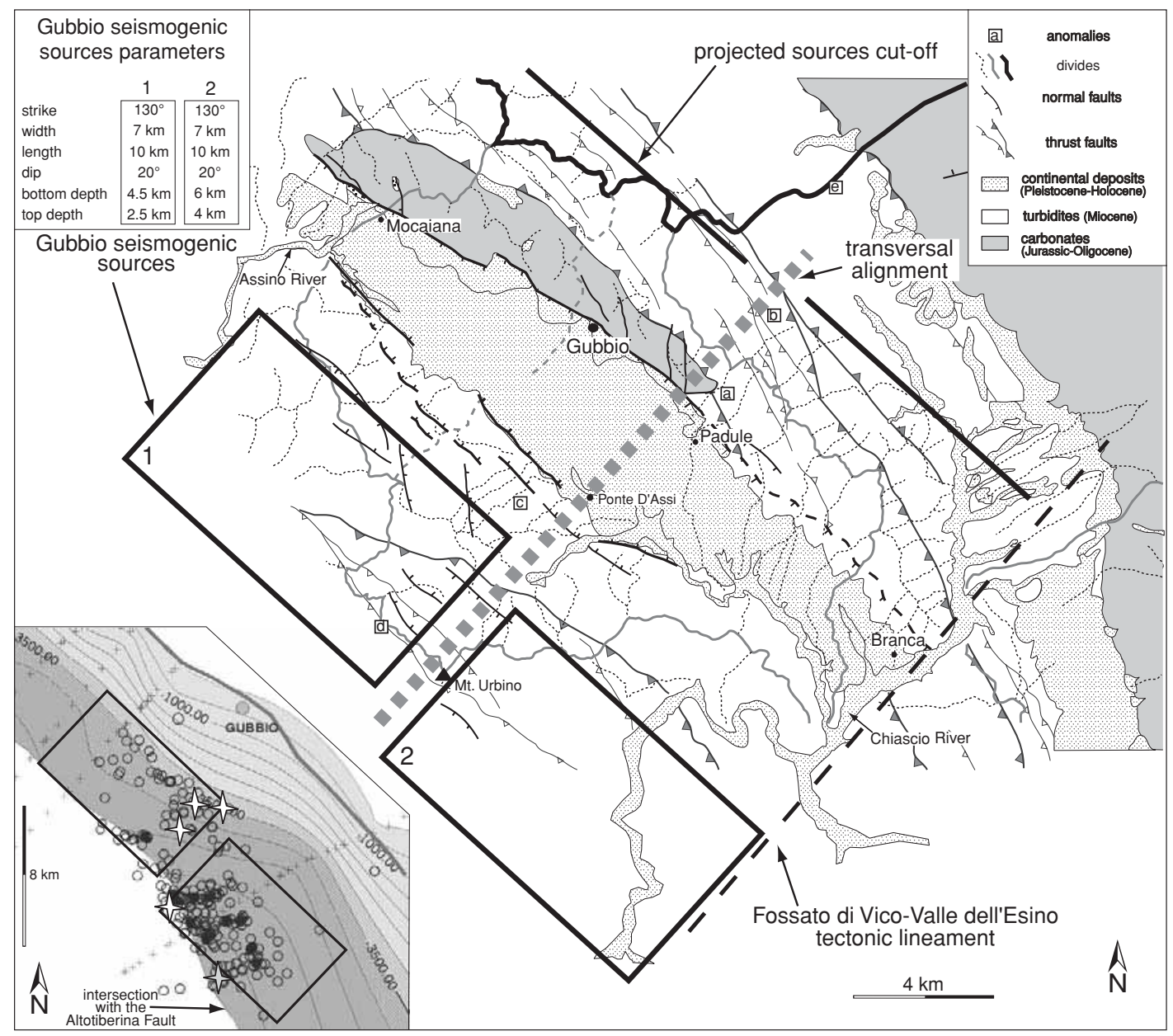

Fig. 16. Hypothesized seismic sources in the Gubbio area. Simplified geology and basin divides are reported. The thick normal faults are the high-angle sections of the Gubbio Fault System. The sources are represented as boxes, which are the projection of the low-angle plain of the Gubbio Fault to the surfaces. Dashed gray line is the hypothetical transversal lineament highlighted by structural and geomorphological anomalies. The inset shows the position of the sources with respect to the reconstruction of the Gubbio Fault isobaths, its intersection with the Altotiberina Fault and the 1984 seismicity (after Barchi et al., 2000, modified). 
c) some Assino River captures (Cattuto, 1973). Seismic reflection profiles suggest that the Gubbio Fault probably continues south-eastward outside the basin (Mirabella, 2003). Because of the total lack of geomorphic evidence we assume this southern part of the fault is the witness of an early, longer structure, not active today. Thus we infer the length of the Gubbio Fault as directly derived from the basin size. The southern boundary is less constrained and coincides with the southern end of the basin marked by the Fossato di Vico-Valle dell'Esino transverse tectonic lineament (Cencetti, 1988; Dramis et al., 1991 and references therein) and with some Chiascio River captures (Cattuto, 1973).

On the basis of the 1984 inferred seismogenic source and of similarities with the geometry of the 1997 , Colfiorito earthquake sources, we may approximate the main seismogenic source of the Gubbio area with the low-angle section of the Gubbio Fault. This corresponds to a $22 \mathrm{~km}$ long, $7 \mathrm{~km}$ wide, $20^{\circ}$ dipping fault plane which, according to Wells and Coppersmith's (1994) empirical relations could produce earthquakes in the magnitude range 5.9 to 6.4

The geomorphic evidence of the Gubbio Fault suggests that this structure has been active for a long time over its entire $22 \mathrm{~km}$ length. However, no strong basis exists for deciding whether the fault will rupture as a whole segment or in shorter independent sections. In both cases the Gubbio Basin would be evidence for long term activity of the fault but in the second case it would be the result of the coalescence of smaller basins. Understanding which of these two scenarios is more realistic has a critical impact on seismic hazard issues.

In the middle part of the basin there is evidence for a NE-SW alignment highlighted by the following anomalies (fig. 16): a) abrupt southern termination of the carbonatic anticline; b) lateral termination of Miocene thrust fronts (Menichetti et al., 1986); c) low hierarchic grade of some NE-SW creeks; d,e) divide and watershed flexures (Cencetti, 1988). This alignment is also consistent with discontinuities within the Altotiberina Fault and the bending of the Gubbio Fault Plane at depth (see inset fig. 16; Barchi et al., 1999, 2000) and may suggest internal complexities of the Gubbio Fault
System that could act as geometric barriers in the propagation of earthquake ruptures. This potential segmentation of the Gubbio Fault System is also in agreement with observations on the 1984 earthquake. As discussed in the previous part of the paper, this $M_{s} 5.3$ earthquake is interpreted to have ruptured the southern part of the low-angle Gubbio Fault. Moreover, the 1984 aftershock distribution shows a peculiar step over zone (Collettini et al., 2003) (inset in figs. 5 and 16) occurring along the NESW alignment.

Based on these considerations we suggest that the Gubbio area may comprise two smaller seismogenic sources whose boundaries are represented by the basin fault system boundaries and by the hypothesized NE-SW transverse alignment (fig. 16). The maximum magnitude expected for these sources can be estimated both by assuming the 1984 earthquake as the typical size earthquake for the area, and also on the basis of the fault length and width using empirical relations (Wells and Coppersmith, 1994). On this basis, these sources may generate $M$ 5.3-5.9 earthquakes. However, the activation of the $22 \mathrm{~km}$ long fault for its entire length cannot be completely ruled out.

No information on the long-term seismic behavior of these sources exists. Taking into account that the historical record of seismicity can be considered complete for $5.0<M<5.6$ in the past 400 years and for $M>5.6$ in the past 800 years (Zonno et al., 2002) and that there is no evidence for 1984-type earthquakes during this period, we expect recurrence intervals longer than four centuries.

\section{Conclusions}

We used geomorphic analysis coupled with DEM analysis and dislocation modeling to understand the present tectonic activity of the Gubbio Basin and infer the potential seismogenic sources threatening the area.

The present setting of the Gubbio Basin appears to be controlled by three main fault sections: two of them form a W-dipping fault known as the Gubbio Fault (fig. 15b, faults 1 and 2), while the third one is a E-dipping high- 
angle fault (fig. 15b, fault 3) antithetic to the Gubbio Fault. The antithetic fault has a clear surface expression and several lines of evidence suggest its recent activity: aligned scarps in young deposits and bedrock, drainage anomalies, basin asymmetry, staircase-like uplifted erosional and depositional surfaces. The existence of this antithetic fault contributes to explain the narrowness of the Gubbio Basin. The Gubbio Fault, which certainly played an important role in the basin construction, does not show sizable ongoing activity. No stratigraphic data are available to decide conclusively if the high-angle section of the Gubbio Fault is: 1) totally inactive; 2) slipping at very low rates (easily compensated by erosional processes), or 3) slips at a substantial slip rate $(>0.5 \mathrm{~mm} / \mathrm{yr})$. Neverthless, we believe that the 1984 earthquake provides living evidence that the lowangle portion of the Gubbio Fault (fault 1) is active.

After testing different combinations of the fault sections of fig. 15b, we conclude that only the joint action of all three faults can fully explain the present setting of the basin (fig. 15f). The antithetic fault and the low-angle section of the Gubbio Fault appear to be the main active features although their long-term contribution is smaller than that of the highangle Gubbio Fault. No firm constraints on the relative age and rates of activity of the different fault sections exist at present.

Rupturing of the whole Gubbio Fault could produce a $M$ 5.9-6.4 earthquake. However, based on the existence of a transverse lineament in the middle part of the basin that may act as a fault boundary, we hypotesize the existence of two smaller, independent seismogenic sources, each one capable of a $M$ 5.3-5.9 earthquake (fig. 16). These sources are represented by low-angle, W-dipping normal faults that may propagate to the surface through the adjoining high-angle sections. The southern source is thought to have ruptured entirely in the 1984 earthquake, but no evidence for earthquakes rupturing the northern source exists in the historical record. Under these circumstances this latter source may be the cause of a future damaging earthquake. The peculiar geometry of these sources and their relatively small size, which sets an upper bound to the size of the expected earthquakes, appears to be a typical feature for this part of the Central Apennines seismogenic belt. This observation may explain the frequent but moderate magnitude earthquakes reported for this region (CPTI, Working Group, 1999) and has important implications on seismic hazard evaluations.

\section{Acknowledgements}

We thanks C. Collettini, F. Mirabella, R. Basili and M. Moro for the constructive discussions and suggestions, T. Tamashvili, M. Marchetti and his group for their field support, and the countess Torlonia-Borghese for permission for working in her land. We are grateful to $\mathrm{M}$. Barchi and M. Meghraoui for their valuable comments and suggestions, which helped substantially in preparing the final version of the paper. This research was funded by the GNDT project «Terremoti probabili in Italia tra l'anno 2000 ed il 2030: elementi per la definizione di priorità degli interventi di riduzione del rischio sismico» and INGV «Seismology and Tectonophysics» Department.

\section{REFERENCES}

BARCHI, M. (1991): Integration of a seismic profile with surface and subsurface geology in a cross-section through the Umbria-Marche Apennines, Boll. Soc. Geol. It., 110, 469-479.

BARCHI, M. (2002): Lithological and structural controls on the seismogenesis of the Umbria region: observations from seismic reflection profiles, Boll. Soc. Geol. It., 1 (spec. vol.), 855-864.

Barchi, M., A. De Feyter, M.B. Magnani, G. Minelli, G. PiALli and B.M. SOTERA (1998): The structural style of the Umbria-Marche fold and thrust belt, Mem. Soc. Geol. It., 52, 557-578.

Barchi, M., S. Paolacci, C. Pauselli, G. Pialli and S. MerLini (1999): Geometria delle deformazioni estensionali recenti nel bacino dell'Alta Val Tiberina fra S. Giustino Umbro e Perugia: evidenze geofisiche e considerazioni geologiche, Boll. Soc. Geol. It., 118, 617-625.

Barchi, M., M. Cardinali, P. Chiraz, C. Collettini, C. Federico, F. Guzzetti, M.B. Magnani, G. Minelli, F. Mirabella, C. Pauselli, G. Pialli, S. Pucci and E. Troiani (2000): Integrazione di dati geofisici e geologici per la caratterizzazione delle strutture sismogenetiche di Colfiorito e di Gubbio, in Le ricerche del 
GNDT nel campo della pericolosità sismica (19961999), edited by F. Galadini, C. Meletti and A. ReBEZ (CNR-Gruppo Nazionale per la Difesa dai TerremotiRoma), 149-156.

Barchi, M., S. Pucci, C. Collettini, F. Mirabella, D. Massoli, F. Guzzetti, P. Reichenbach, M. Cardinali, N. Vergoni, E. Troiani, P. Chiraz and L. Giombini (2001): A geologic map of the Colfiorito area, in Geoitalia, $3^{\circ}$ Forum FIST poster session, 333-334.

BARTolini, C. (1992): I Fattori Geologici delle Forme del Rilievo (Pitagora Ed., Bologna), pp. 193.

Bonarelli, G. (1891): Il territorio di Gubbio, Notizie Geologiche (Roma), pp. 38

Bonarelli, G., T. Lipparini, A. Moretti, C. Pillotti, P PrinciPI, F. SCARSElla and R. Selli (1952): Carta geologica d'Italia 1:100000, Italian Geological Survey, 1st edition, sheet 116, Gubbio.

Boncio, P., F. BROZZETTI and G. LAVECCHIA (1996): State of stress in the Northern Umbria-Marche Apennines (Central Italy): inferences from microearthquake and fault kinematic analyses, Ann. Tectonicae, 10 (1/2), 8097.

Boncio, P. F. Brozzetti, F. Ponziani, M. Barchi, G. LaVeCCHIA and G. Pialli (1998): Seismicity and extensional tectonics in the Northern Umbria-Marche Apennines, Mem. Soc. Geol. It., 52, 539-555.

BRANCONI, P. and D. MANCONI (1982-1983): Gubbio: nuovi scavi a via degli Ortacci, Ann. Fac. Lett. Fil., Studi Classici (Perugia), XX, 81-159.

BULL, W.B. and L.D., MC FADDEN (1977): Tectonic geomorphology north and south of the Garlock Fault, California, in Geomorphology in Arid Regions: Binghamton, N.Y., edited by D.O. DoEHRING, State University of New York at Binghamton, 115-138.

Cattuto, C. (1973): Carta dei lineamenti geomorfologici del territorio di confluenza tra il F. Chiascio ed i Torrenti Rasina e Saonda, Geol Romana, 12, 105-124.

Cencetti, C. (1988): Evoluzione del reticolo idrografico in un tratto umbro-marchigiano dello spartiacque principale dell'Appennino, Geogr. Fis. Dinam. Quat., 11, 11-24.

Collettini, C. (2001): Architecture geometry and mechanics of the Northern Apennine seismogenic normal faults, Unpublished Ph.D. Thesis, University of Perugia, (Italy), pp. 177.

Collettini, C., L. Chiaraluce, F. Mirabella, S. Pucci and M.R. BARCHI (2003): The Gubbio seismogenic normal fault: can different methods picture the same object?, J. Geodyn. (in press).

CPTI, Working Group (1999): Catalogo Parametrico dei Terremoti Italiani (ING, GNDT, SGA, SSN, Bologna), pp. 92.

Damiani, A.V., L. Pannuzi and G. Pialli (1983): Osservazioni geologiche nelle aree comprese fra $\mathrm{i}$ Massicci Perugini ed i rilievi di Gubbio, G. Geol., 45 (2), 127-150.

Deschamps, A., R. Scarpa and G. SelvagGi (1989): Analisi sismologica del settore settentrionale dell'Appennino Umbro-Marchigiano, in Proceedings of the $8^{\circ}$ Meeting GNGTS, Rome, 9-15.

Dramis F., G. Pambianchi, O. Nesci and M. Consoli (1991): Il ruolo di elementi strutturali trasversali nell'evoluzione tettonico-sedimentaria e geomorfologica della regione Marchigiana, in Studi Preliminari all'Acquisizione Dati del Profilo CROP 11 Civitavecchia-Vasto, edited by M. TOZZI, G.P. CAVINATO and M. Parotto, Studi Geologici Camerti, 2 (spec. vol.), 397-406.

Dziewonski, A.M., J.E. Franzen and J.H. WoOdhouse (1985): Centroid-moment tensor solutions for AprilJune, 1984, Phys. Earth Plan. Int., 37, 87-96.

Doglioni, C., N. D’Agostino and G. Mariotti (1998): Normal faulting versus regional subsidence and sedimentation rate, Mar. Pet. Geol., 15, 737-750.

Ekström, G., A. Morelli, E. Boschi and A.M. Dziewonski (1998): Moment tensor analysis of the Central Italy earthquake sequence of September-October 1997, Geophys. Res. Lett., 25 (11), 1971-1974.

GE.MI.NA (1963): Ligniti e Torbe dell'Italia Centrale (GE.MI.NA., Geomineraria Nazionale, Torino), pp. 319.

Giaquinto, S., G. Marchetti, A. Martinelli and E. Martini (1991): Le Acque Sotterranee in Umbria (Protagon Eds., Perugia), pp. 212.

Haessler, H., R. Gaulon, L. Rivera, R. Console, M. Frogneux, G. Gasparini, L. Martel, G. Patau, M. Siciliano and A. Cisternas (1988): The Perugia (Italy) earthquake of 29 April 1984: a microearthquake survey, Bull. Seismol. Soc. Am., 78 (6), 1948-1964.

INGV (1985-2000): Monthly Earthquake Bulletin, http:// //www.ingv.it/ (Istituto Nazionale di Geofisica e Vulcanologia, Roma, Italy).

ISC (2001): On-line Bulletin, http://www.isc.ac.uk/Bull (International Seismological Centre, Thatcham, U.K.).

LaveCChia, G. and G. Pialli (1980): Appunti per uno schema strutturale dell'Appennino Umbro-Marchigiano. 2) La copertura, Studi Geologici Camerti, 4, 23-30.

LONA, F. and R. BERTOLdI (1972): La storia del PlioPleistocene italiano in alcune sequenze vegetazionali lacustri e marine, Mem. Accad. Naz. Lincei, 11, 1-47.

Menichetti, M. (1992): Evoluzione tettonico-sedimentaria della valle di Gubbio, Studi Geologici Camerti, 1 (spec. vol.), 155-163.

Menichetti, M. and G. Pialli (1986): Geologia strutturale del preappennino umbro tra i monti di Gubbio e la catena del M. Petrano-M. Cucco, Mem. Soc. Geol. It., 35, 371-388.

MenichetTi, M. and G. Minelli (1991): Extensional tectonics and seismogenesis in Umbria (Central Italy) the Gubbio area, Boll. Soc. Geol. It, 110, 857-880.

Mirabella, F. (2003): Seismogenesis of the Umbria-Marche region (Central Italy): geometry and kinematics of the active faults and mechanical behavior of the involved rocks, Ph.D. Thesis, University of Perugia (Italy).

Moretti, A. and U. Perno (1968): Carta geologica d'Italia 1:100000, Italian Geological Survey (2nd edition), sheet 123 , Assisi

SelvagGi, G. and S. Sylos Labini (1989): Analisi sismotettonica del bacino di Gubbio, in Proceedings of the $8^{\circ}$ Meeting GNGTS, Rome, 67-72.

VAlEnsise, G. and D. PANTOSTI (2001a). The investigation of potential earthquake sources in peninsular Italy: a review, J. Seismol., 5, 287-306.

VAlensise, G. and D. PANTOSTI (Editors) (2001b): Database of potential sources for earthquakes larger than $M 5.5$ in Italy, Ann. Geofis., 44 (suppl. to n. 4), pp. 180 (with CD-ROM). 
WARD, S.N. and G. VALENSISE (1989): Fault parameters and slip distribution of the 1915, Avezzano, Italy earthquake derived from geodetic observations, Bull. Seismol. Soc. Am., 79, 690-710.

Wells, D.L. and K.J. Coppersmith (1994): New empirical relationships among magnitude, rupture length, rupture width, rupture area and surface displacement, Bull. Seismol. Soc. Am., 84 (4), 974-1002.
Westaway, R., R. Gawthorpe and M. Tozzi (1989): Seismological and field observations of the 1984 Lazio-Abruzzo earthquakes: implications for the active tectonics of Italy, Geophys. J., 98, 489514.

ZONNO, G., V MONTALDO and I. LESCHIUTTA (2002): Valutazione della pericolosità sismica in alta Valtiberina, Ing. Sismica, 1, 33-43. 